\title{
Revision of the genus Eucyclops (Claus, 1893) and subfamily Eucyclopinae of the world fauna
}

\author{
Ревизия рода Eucyclops (Claus, 1893) \\ и подсемейства Eucyclopinae мировой фауны
}

\author{
Victor R. Alekseev \\ Виктор P. Aлексеев
}

\begin{abstract}
Zoological Institute of the Russian Academy of Sciences, Universitetskaya emb., 1, St.-Petersburg, 199034 Russia. E-mail: alekseev@zin.ru Зоологический институт РАН, Университетская наб., д.1, Санкт-Петербург, 199034 Россия.
\end{abstract}

KEY WORDS: new genera in Eucyclops, new subgenera in Eucyclops, copepoda systematics, species key, Crustacea subgenus description, biodiversity.

КЛЮЧЕВЫЕ СЛОВА: новые роды Eucyclops, новые подроды Eucyclops, систематика копепод, видовые ключи, описание подродов, видовое разнообразие.

ABSTRACT. The revision of the most rich with species genus Eucyclops Claus, 1893 was done. The genus Austriocyclops Kiefer, 1964 has been moved back to the subfamily Cyclopinae, as Kiefer suggested. The status of the genus Australoeucyclops Karanovic, 2006 is lowered to subgenus, and the status of the subgenus Defayeicyclops Alekseev et Vaillant, 2013 is erected to genus. Two new genera (former subgenera) Isocyclops Kiefer, 1957 stat.n. and Stygocyclops Pleša, 1971 stat.n. were erected from the genus Eucyclops. A key for 12 genera of the subfamily Eucyclopinae is given. Genus Eucyclops including about 100 valid species was split into 9 subgenera: Eucyclops (Eucyclops), Eucyclops (Breviramocyclops), Eucyclops (Ciliocyclops), Eucyclops (Denticyclops), Eucyclops (Macrurocyclops), Eucyclops (Mrazekicyclops), Eucyclops (Sarsicyclops), Eucyclops (Speratocyclops), and Eucyclops (Subterrocyclops). Descriptions and illustrations are provided for typical species, as well as keys to 9 new subgenera of Eucyclops genus and to subfamily Eucyclopinae. For each subgenus, the total number of species and identifying keys for them are provided.

How to cite this article: Alekseev V.R. 2019. Revision of the genus Eucyclops (Claus, 1893) and subfamily Eucyclopinae of the world fauna // Arthropoda Selecta. Vol.28. No.4. P.490-514. doi: 10.15298/arthsel. 28.4.03

РЕЗЮМЕ. Проведена ревизия подсемейства Eucyclopinae с выделением ряда новых родов. Род Austriocyclops Kiefer, 1964 перемещен обратно в подсемейство Cyclopinae, как это предполагал Кифер. Статус рода Australoeucyclops Karanovic, 2006 понижен до подрода, а статус подрода Defayeicyclops Alekseev et Vaillant, 2013 поднят до рода. Из состава рода Eucyclops выделены два новых рода (прежние подроды) Isocyclops Kiefer, 1957 stat.n. и Stygocyclops Pleša, 1971 stat.n. Приведен определи- тельный ключ для 12 родов подсемейства Eucyclopinae. Оставшиеся виды рода Eucyclops разделены на 9 новых подродов: Eucyclops (Eucyclops), Eucyclops (Breviramocyclops), Eucyclops (Ciliocyclops), Eucyclops (Denticyclops), Eucyclops (Macrurocyclops), Eucyclops (Mrazekicyclops), Eucyclops (Sarsicyclops), Eucyclops (Speratocyclops), and Eucyclops (Subterrocyclops). Приводятся описания и иллюстрации для типовых видов каждого из подродов, а также определительные ключи для 9 новых подродов и подсемейства Eucyclopinae в целом. Для каждого подрода указывается общее количество видов и определительные ключи для них.

\section{Introduction}

The genus Eucyclops Claus, 1893 is the largest one among continental cyclopids [Alekseev et al., 2006; Alekseev, Defaye, 2011]. Even after separation of two former subgenera Isocyclops Kiefer, 1957 and Stygocyclops Pleša, 1971 the genus Eucyclops comprises about one hundred species and 15 subspecies [Dussart, Defaye, 2006; Alekseev, Defaye 2011; Mercado-Salas, Suárez-Morales, 2014]. Being one of the largest genus among continental copepods it has not been completed yet as within last decade new forms were being described at regular basis. The last revision of the whole genus was done by Lindberg [1957]. After his paper devoted to African Eucyclops and provided with a key for about 40 described for this time species only several regional revisions of Eucyclops were fulfilled: for Australia by Morton [1990], for Ukraine by Monchenko [1974], for Japan by Ishida [2002], for Mexico by Mercado-Salas \& Suárez-Morales [2014], for Palearctic by Alekseev \& Defaye [2011]. Altogether more than 120 taxons were described up to now that is difficult to manage with and create effective identification keys. The fast-going and dramatic changes in biogeog- 

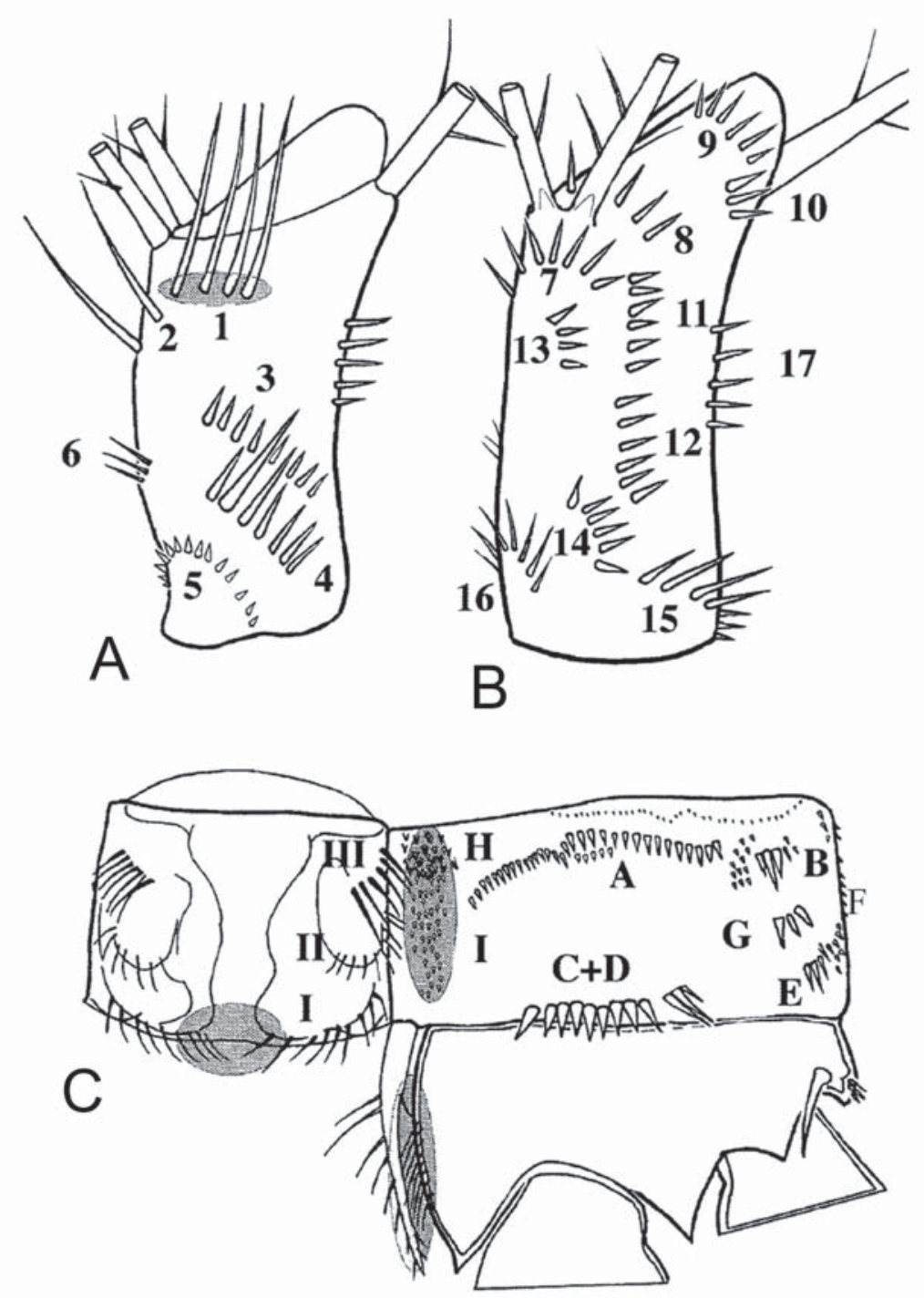

Fig. 1. Numbering system for micromorphological patterns in Eucyclops: A - basipodite of A2, posterior; B - A2 basipodite, anterior; C - intercoxal sclerite and coxa of P4. Orig.

Рис. 1. Система нумерации для микроморфологической картины у Eucyclops: А - базиподит А2, вид сзади; В - базиподит А2, вид спереди; С - соединительная пластинка и коксоподит Р4. Ориг.

raphy and biodiversity of continental invertebrates caused by climate changes and bioinvasions set up the necessity to provide taxonomists with world faunistic keys. This study is devoted to revision of Eucyclops and creating of new system within the genus to make species identification more easy and reliable.

Redescription of the type for genus Eucyclops serrulatus (Fischer, 1851) [Alekseev et al., 2006] with using of plenty methods including molecular-genetic and interspecific hybridization revealed several microcharacters important for species identification as ornamentation of antenna (A2) basipodite and swimming leg 4 (P4) coxopodite with coxal spine (Fig. 1). Along with traditionally used morphological features including antennule segmentation, proportions in distal segments and spines/seta of endopodite (Enp) and ex- opodite (Exp) of P4 and caudal rami, relative length of antennule (A1) and construction of hyaline plate at three distal segments, rudimental leg 5 (P5) construction and armament in female, and leg 6 (P6) in males these characters were used here for subgenus separation, description and identification keys creation. For practical reasons and due to morphological similarities 9 subgenera were erected.

\section{Material studied}

Several important collections of freshwater cyclopids were studied that included: Prof. Kiefer reference collection placed in Karlsruhe, Germany; Prof. Henry Dumont collection of African species (mainly Tanganyika and Victoria Lakes) in Ghent University, Belgium; Prof. C.H. Fernando 
collection (University Waterloo, Canada), Singapore University; Prof. T. Ishida type collection sent by him to Zoological Institute of RAS; Prof. B. Dussart collection in Natural History National Museum, Paris, France; Prof. V. Monchenko type collection of Eucyclops in Institute of Zoology, Kiev, Ukraine; Prof. G.O. Sars collection in Natural History Museum, London (G. Boxshall as curator); Prof. G. Mazepova collection of Baikalian copepods in Limnological Institute, Irkutsk, Russia; Prof. A. Brancelj copepod collection from Slovenia caves in National Institute of Biology, Ljubljana, Slovenia; Prof. M. Miraclea zooplankton of mountain reservoirs of the Central Spain (University of Valencia, Spain); Prof. D. Defaye collection in National Museum of Natural History, Paris, France; Prof. F. LescherMoutoué personal collection; Prof. E. Borutzky collection, Zoological Museum of Moscow State University, Russia; Prof. L. Sanoamuang tropical zooplankton collection (University of Khon-Kaen, Thailand); Anna Kosova zooplankton collection of the river Volga delta (Astrakhan State Reservation, Astrakhan, Russia). Furthermore, Victor Alekseev personal copepod collection that includes samples from following countries: Russia (all regions), Ukraine, Georgia (Kura River and its tributary), Armenia (Sevan Lake, Hrazdan River), Uzbekistan (Syr Darya River, waterbodies in Fergana Valley), Kazakhstan (Aral Sea, Lake Balkhash), Kirgizia (Issyk-Kul mountain lake), Hungary (Danube River, Lake Balaton), France (lakes in Boulogne park, Paris; botanical garden in Wimereux; Marseille vicinity etc.), Belgium (Ghent vicinity), Norway (vicinity of Bergen and Oslo), Sweden (vicinity of Lund and Stockholm), Germany (vicinity of Lübeck, Hamburg and Plön), Denmark (vicinity of Copenhagen), Finland (vicinity of Helsinky, Turku, Mariehamn, Gulf of Bothnia), Spain (Albufera Lake, Turia River, Guadalquivir River, waterbodies in vicinity of Valencia, Barcelona and Madrid), Portugal (vicinity of Lisboa), Poland (vicinity of Kraków, Wrocław, Warsaw, Masurian lakes), Italy (vicinity of Rome, Venice and Florence, the Tiber River), Ireland (vicinity of Dublin), Turkey (vicinity of Istambul, Anatolia, small rivers along the sea coast), Northern Macedonia (Lake Ohrid), Israel (springs in desert, Lake Kinneret), Egypt (The Nile Delta near Cair), Tunisia (small rivers and waterbodies along sea coast in Tunis city and Hammamet district), Ethiopia (the White Nile and Blue Nile, large lakes in the Lake Valley), Mongolia (the Selenga river with tributaries, rivers and lakes in Gobi desert, Uvs Lake), China (the Yellow River (Huang He), Yangtze River and Pearl River, waterbodies in Hainan, Hong-kong islands, waterbodies in Beijing vicinity, Shanghai vicinity, Guangzhou vicinity), Japan (vicinity of Tokyo, Hiroshima, Kyoto), Taiwan (Moon lake, small rivers along sea coast in Northern and Southern parts, vicinity of Taipei and Kaohsiung), Laos (the Mekong River), Vietnam (vicinity of Hanoi, Da Nang and Ho Chi Minh City, the Mekong Delta), Malaysia (vicinity of Kuala Lumpur, Borneo island), Singapore, Tailand (vicinity of Bangok and Khon-Kaen), Cambodia (the Mekong River), Indonesia (vicinity of Jacarta, Ci Liwung River, Java island), Australia (vicinity of Sydney, Melbourne, Dr. D. Lajus as collector), USA (lake Erie, vicinity of NewYork and Washington), Canada (lakes in Quebec province, lakes and rivers in Ontario province), Mexico (vicinity of Mexico city, Acapulco, Cozumel island, lakes and rivers in Yucatan Peninsula). Most of type slides of Eucyclops species described by Kiefer and Dussart were observed and used for personal drawing by VA. Neotypes of several species described by Fischer and Lilljeborg were established from the type localities. Altogether more than $60 \%$ of known Eucyclops species were observed and used for comparison. All the rest species were studied on authors' descriptions.

\section{Methods}

A classical taxonomical method of external morphology examination has been used. Adult females and males before dissecting were pictured from dorsal side for a common view of animal with a 12-megapixel digital photo camera equipping Zeiss Imager.A1 microscope. Then specimens were dissected in a drop of glycerol on a microscope glass covered with a cover glass supported by droplets of plasticine on opposite corners to prevent damage of taxonomically important parts. Drawings were made at $400-1000 x$ magnification with microscope equipped with Nomarski optics and a camera lucida, converted in ink than digitized with scanner (resolution $1200 \mathrm{dpi}$ ) and used for mounting in table of drawing. Each picture was provided with a scale bar. Along with classical morphological features (number of spines, setae, segments of A1, P1-P6, caudal rami shape, proportion and armament, several new microcharacters were selected for Eucyclops revision that includes ornamentation of basipodite A2 with groups of hairs and denticles counted as 1-24, length and pinnation of coxal spine/seta in swimming leg 4, ornamentation of caudal side of coxal plate in P4; pinnation of inner outgrowth P4 basipodite (see Fig. 1). Stability of the microcharacters within species and variation of them among distant populations of Eucyclops species were studied in hybridization examining for the type species of the genus Eucyclops serrulatus (Fischer, 1851) [Alekseev et al., 2006].

All Eucyclops species slides obtained and used for the genus revision were catalogized and placed in the Federal Collection of Zoological Institute of RAS \#96-03-16.

\section{Results}

Since the genus erection [Claus, 1893] as cyclopid with unisigmented P5 armed with three appendages this genus was partly revised by Kiefer who separated Tropocyclops [Kiefer, 1960], Thaumasiocyclops [Kiefer, 1930], Ochridacyclops [Kiefer, 1937] and by Sars [1927] who described Afrocyclops. All these genera were separated each from other as well from other Eucyclopinae genera by armament of P5 - the most important feature for cyclopid system on above species level, and segmented or not segmented rudimental leg body (Ochridacyclops, Thaumasiocyclops). Later on only two subgenera were established by Pleša [1971] and Kiefer [1957] both on armament of P5 with two appendages in monotypic Stygocyclops and relatively long segment of P5 with length/width (L/W) ratio 1.61.8 and unusually long lateral seta of caudal rami that is clearly longer than outermost seta and more that 22.5 times longer than ramus width in Isocyclops when in Eucyclops sensu stricto inner appendages of P5 always presented with more or less strong spine clear different from middle and outer setae. To my mind, so large differences in P5 construction have to be recognized as genus level features. Hereafter these two small subgenera are redescribed as genera under the same 


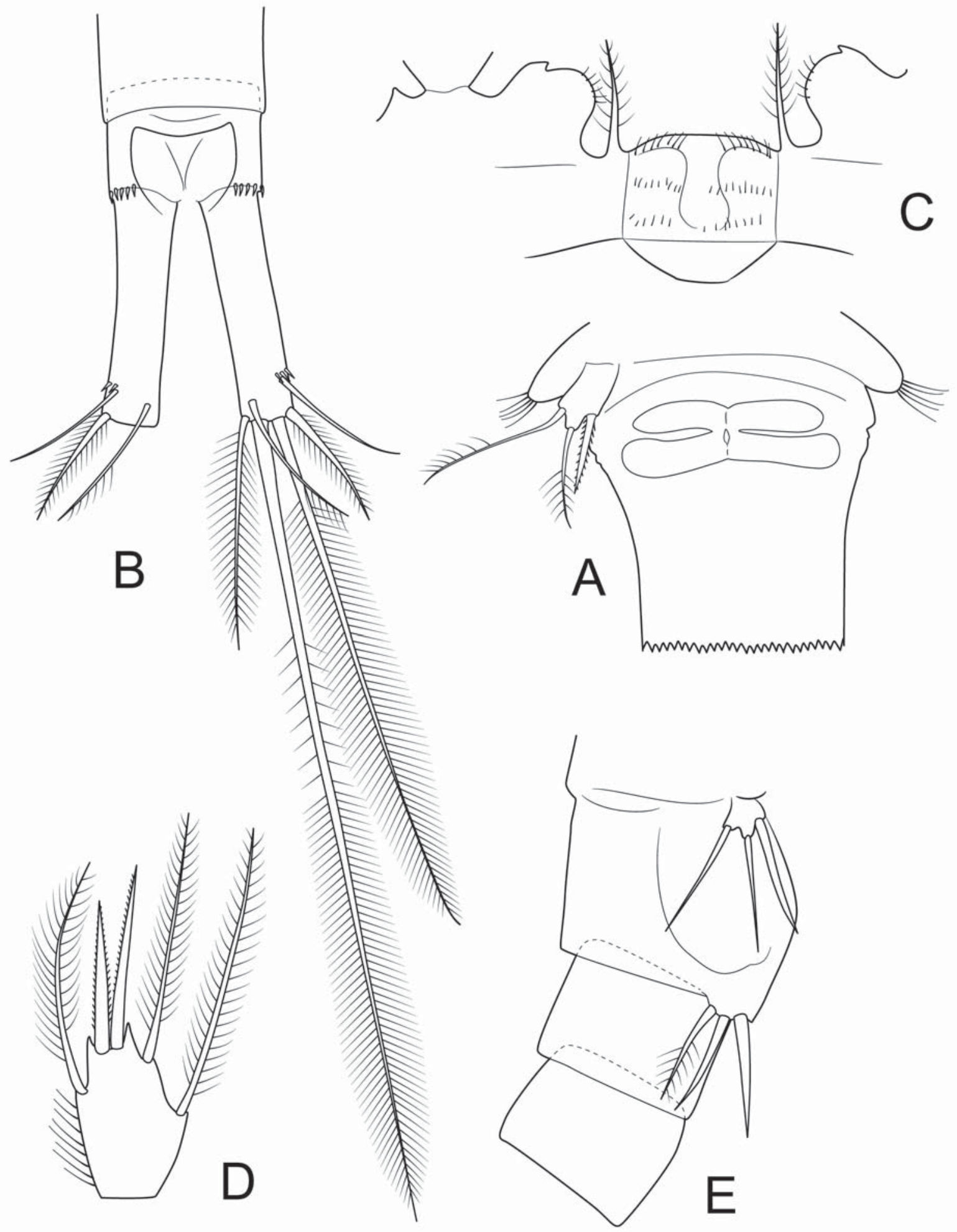

Fig. 2. Isocyclops caparti Lindberg, 1951 stat.n.: A - genital segment and P5, ventral; B - caudal rami, dorsal; C - P4 coxal connective plate; D - distal segment of endopodite P4; E - P5 \& P6, O’. Redrawn from Lindberg, 1951.

Рис. s. Isocyclops caparti Lindberg, 1951 stat.n.: А — генитальный сегмент и P5, вентрально; В — каудальные ветви, дорсально; C - соединительная пластинка P4; D - дистальный сегмент эндоподита P4; E - P5 \& P6, O'. Воспроизведено по Lindberg, 1951. 

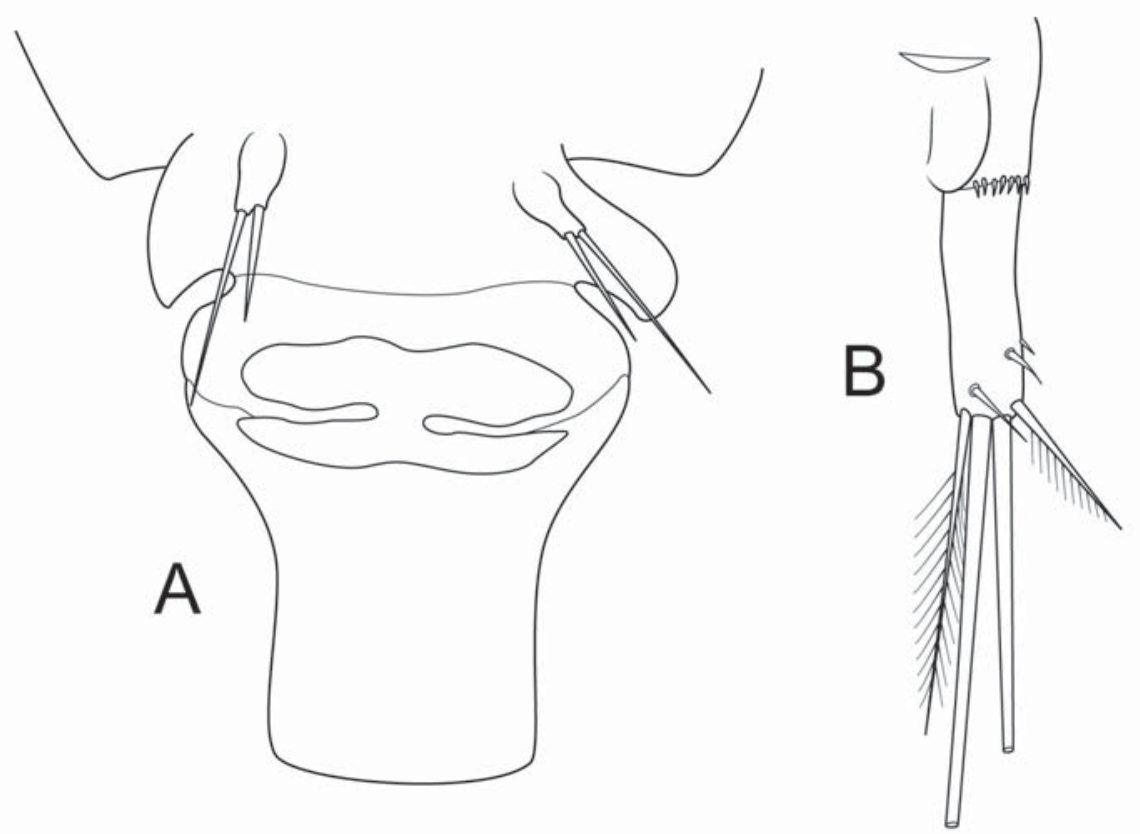

Fig. 3. Stygocyclops teras (Graeter, 1907) stat.n.: A — genital segment and P5, ventral; B — caudal ramus, dorsal. Redrawn from Graeter, 1907.

Рис. 3. Stygocyclops teras (Graeter, 1907) stat.n.: А — генитальный сегмент и Р5, вентрально; В — каудальная ветвь, дорсально. Воспроизведено по Graeter, 1907.

names and authors: genus Isocyclops Kiefer, 1957 stat.n. and genus Stygocyclops Pleša, 1971 stat.n. One more subgenus Tropocyclops (Defayeicyclops) that has P5 with 2 long setae instead of 3 and includes now two species T. (Defayeicyclops) jamaicensis (Reid et Janetzky, 1996) and D. matanoensis (Defaye, 2007) also should be erected till genus level. So far in the key for Eucyclopinae subfamily genera I include: Eucyclops, Tropocyclops, Afrocyclops, Thaumasiocyclops, Ochridacyclops, Paracyclops, Ectocyclops, Macrocyclops, Defayeicyclops, Isocyclops, Stygocyclops, Homocyclops.

\section{Brief description of new erected genera}

\section{Genus Isocyclops Kiefer, 1957 stat.n.}

Type species: I. caparti Lindberg, 1951 (Fig. 2).

FEMALE. Moderate length 840-940 $\mu$ with relatively short 12-segmented antennule just reaching cephalothorax distal edge; three distal segment A1 provided with smooth hyaline membrane. The 4 th free thoracal segment with dense group of long spinules laterally, genital double-somite about as long as wide. Swimming legs with 3 -segmented exopodite and endopodite, spinal formula 3/4/4/3. Distal segment endopodite 4 with both distal spines (or at least outer one) longer than segment; distal seta exceeding distal ends of nearest spine. Coxal spines homogenously covered with spinules, coxal connective plate with three rows of very short hairs, inner outgrowth of basipodite round shaped but with small reduced angular protrusion. P5 very long, L/W ratio $1.6-1.8$ with relatively weak inner spine subequal or shorter that outermost seta. Caudal rami clearly divergent without lateral serra or with significantly reduced into 6-8 denticles near lateral seta, which is very long, longer than outermost seta and about $2-2.5$ as long as ramus width. Outermost seta subequal in length or even longer than ramus length. Dorsal seta about as long as outermost seta; innermost seta 1.6-1.9 times as long as outermost seta.

MALE. Smaller than females 650-680 $\mu \mathrm{m}$. Caudal rami divergent but shorter than in females. P5 similar to females. P6 with strong inner spine and two subequal in length but more weak setae only reaching to the distal end of next abdominal segment.

The genus comprises two species $I$. caparti Lindberg, 1951 and I. paucidenticulatus Lindberg, 1951 both are endemics of lake Tanganyika (Africa).

\section{Genus Stygocyclops Pleša, 1971 stat.n.}

Type species: S. teras (Graeter, 1907) (Fig. 3).

FEMALE. Moderate length about $1000 \mu \mathrm{m}$. Common view, relative length of antennule similar to E. serrulatus, body color in contrast missing. Forth free thoracal somite without lateral setules, caudal rami without saw. Swimming legs 3-segmented; exopodite spine formula 3/4/4/3; endopodite $\mathrm{P} 4$ elongated (L/W ratio more than 2.3), outer/ inner spine ratio 1.6, distal setae reaching beyond distal tips of nearest spines. Genital double-somite elongated L/W ratio more than 1 with distal part of cylindrical shape. Caudal rami parallel or slightly divergent about 3.2-4.6 times as long as wide, practically without saw on lateral edge with only few small dents near lateral seta insertation place. Outer middle seta about half of inner middle seta or even shorter. Innermost seta clearly longer than ramus length and about 2.5 times as long as outermost seta; dorsal seta about as long as outermost seta; lateral seta 1.25 as long as ramus width. Rudimental P5 elongated shape 1.4 times as long as 


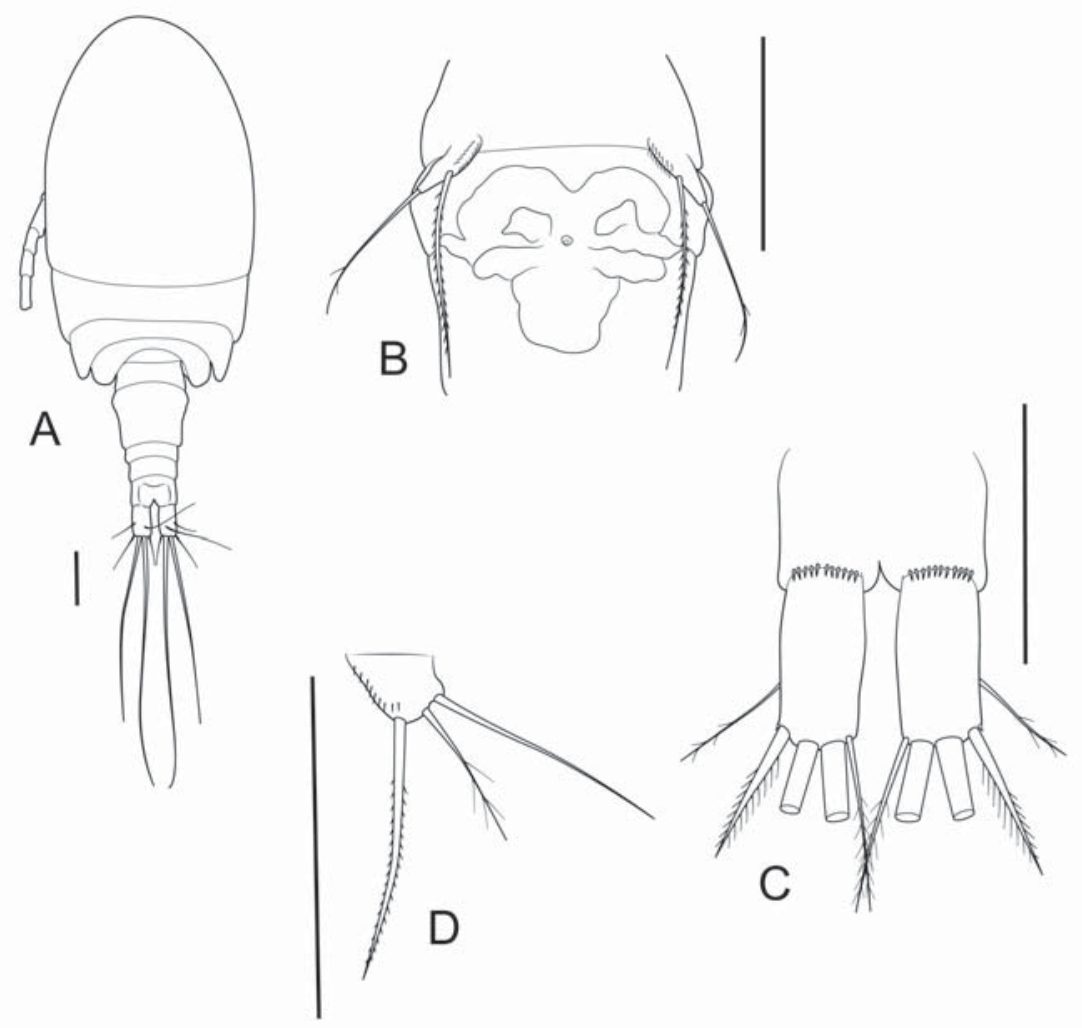

Fig. 4. Defayeicyclops jamaicensis (Reid et Janetzky, 1996) stat.n.: A — habitus, dorsal; B — genital segment and P5, ventral; C caudal rami, ventral; D - P6, O'. Scale bars: $50 \mu \mathrm{m}$. Redrawn from Reid et Janetzky, 1996.

Рис. 4. Defayeicyclops jamaicensis (Reid et Janetzky, 1996) stat.n.: А - общий вид, дорсально; В — генитальный сегмент и P5, вентрально; С - каудальные ветви, вентрально; D - P6, О․ Масштабные шкалы: 50 m. Воспроизведено по Reid et Janetzky, 1996.

broad with only 2 appendages (two naked setae), inner seta longer than outer seta or they subequal in length, outer seta seems like missing. Connecting coxal plate in P4 with long hairs along distal edge; coxal spine significantly longer than inner outgrowth of basipodite, the last looks similar to E.serrulatus.

MALE. Smaller than female 700-900 $\mu \mathrm{m}$ with a parallel caudal rami, slightly shorter than in female. P5 similar to female with 2 appendages. P6 close to E.serrulatus with strong inner spine and two weak shorter setae, outer seta slightly longer than medial seta.

The monotypic genus presented with only one species $S$. teras (Grater, 1907) found in underground water of Switzerland.

Genus Defayeicyclops Alekseev et Vaillant, 2013 stat.n.

Type species: D. jamaicensis (Reid et Janetzky, 1996) (Fig. 4).

FEMALE. Small-sized cyclopid (600-700 $\mu \mathrm{m})$ widest at the posterior part of cephalothorax. The $4^{\text {th }}$ free thoracal somite without long posterolateral setules, but sometimes with row of short spinules presence on lateral margins. Genital double-somite elongated and about 1.5 times longer than broad, with butterfly-like shaped seminal receptacle in anterior part differed from the same in Tropocyclops. Anal oper- culum smooth without denticles or hairs. Caudal rami rather short, about 2 times longer than wide or even less, without hair-like spinules or denticles on lateral margins and on dorsal and ventral surfaces; with the usual 6 setae. Caudal setae: lateral seta inserted near middle of lateral margin of caudal rami; outermost and innermost setae of similar length and slightly longer than ramus; dorsal seta about twice the length of caudal rami and clearly longer than outermost seta. Antennule 12-segmented and long, reaching at least second thoracal somite. Antenna 4-segmented. P1-P4 with 3-segmented rami; exopodite spine formula $3 / 4 / 4 / 3$ or $3 / 4 / 3 / 3$. Distal segment endopodite P4 2.4-2.7 times longer than broad, medial terminal spine about 1.6-1.8 times longer than article, lateral terminal spine subequal to article. Elongated P5 one-segmented, more or less oval in lateral view, ornamented laterally with small, distal row of short spinules; and bearing 1 long spine inserted on the inner margin subapically and 1 apical seta subequal to spine.

MALE. Smaller than female $400-500 \mu \mathrm{m}$ with 14 -segmented geniculate antennule. Segmentation and armature of P1-P4 identical to those in female. P5 one-segmented with 2 appendages similar to that of female, but with longer seta and a spine. P6 composed of 3 elements inserted close to each other on a small plate: 1 strong inner spine, 1 small and thin median seta, and 1 outer seta subequal to inner spine.

COMMENTS. The genus is distinguished from Tropocyclops and other genera of the family by combination of following characters: by the armature of P5 with one seta 
and one spine; absence of lateral hairs on $4^{\text {th }}$ thoracal free somite substituted with small spinules, the special shape of the seminal receptacle in female.

Based on P5 morphology only, the new genus might be placed in the Cyclopinae subfamily, as the free (distal) segment of P5 bears two setae in the genus Defayeicyclops. At the same time, it shares several characters with Tropocyclops such as: the shape and size of the body, the relative length and segmentation of A1, the segmentation and spine/ seta armament of the swimming legs. The inner margin of the BAS of P4 is rounded in Defayeicyclops, similarly to Tropocyclops species, yet differentiating it from Eucyclops and most Cyclopinae species.

Defayeicyclops differs from Tropocyclops in the characters as follows: i) the fifth leg is armed with two elements only (bearing three elements in Tropocyclops); and ii) anterior part of the seminal receptacle is butterflyshaped (with horn-like processes in Tropocyclops).

Defayeicyclops currently comprises 2 species: D. jamaicensis (Reid et Janetzky, 1996) from Jamaica and D. matanoensis (Defaye, 2007) from Sulawesi. The representatives of the new genus were found in highly separated regions (tropical islands in the Pacific and Atlantic oceans).

\section{Key to subfamilies of Cyclopidae}

1. A1 21 segmented .. Subfamily Euryteinae

- A1 6-18 segmented

2. Distal segment P5 with 4-5 appendages ..... . Subfamily Halicyclopinae

- Distal segment P5 with 1-3 appendages ........................... 3

3. Distal segment P5 with 3 appendages (rarely with 2, then P5 unisegmented bearing 2 long subequal setae) ........... Subfamily Eucyclopinae

- Distal segment P5 with 1-2 appendages (unisegmented P5 bears only one long seta ............ Subfamily Cyclopinae

After erection of three new genera subfamily Eucyclopinae one can count 14 genera. This number should be discussed meanwhile.

At first some comments should be done about position of the recently described Australoeucyclops Karanovic, 2006. Description of this genus in fact fits very well to definition Paracyclops done by Kiefer [1927]. Few small morphological differences and claiming of Karanovic on geographical isolation of this group of species are in contradiction to his own mentioning on the leading role of P5 construction in cyclopid genera separation. To my mind, Australoeucyclops should be lowered to subgenus level in the frame of Paracyclops genus.

Austriocyclops Kiefer, 1964, the second case, after redescription by Pospisil \& Stoch [1997] was replaced from Cyclopinae to Eucyclopinae family on the base of not well studied of other genera details. Indeed it seems like this genus occupies intermediate position between Eucyclopinae and Cyclopinae subfamilies, but, to my mind, Austriocyclops more close to Cyclopinae. My reasons are as following: missing of any setules along lateral edge $4^{\text {th }}$ thoracal free somite; P5 seems like was 2-segmented with fused basis bearing lateral seta and tiny distal segment (as in some Microcyclops). Construction of similar receptaculum seminis can be found in some genera of Cyclopinae subfamily; 10-11-segmented antennule also is common in above mentioned subfamily. Only presence/absence aesthetascs on antennule in male and female and some patterns of basipodite of antenna, that are not well studied in most genera of cyclopids, are not convincing enough for replacing of Austriocyclops to Eucyclopinae subfamily. More clear conclusion could be done if we knew morphology of naupliar stages in Austriocyclops. Also molecular-genetic based phylogeny could be useful in this case. This genus possibly occupies intermediate position between Diacyclops and Microcyclops families. Until additional information appears I propose to not include Austriocyclops into Eucyclopinae subfamily and to leave Kiefer's definition.

After these comments I include in subfamily Eucylopinae 11 genera that can be separated with the help of the following key.

\section{Key to Genera of Subfamily EuCyCLOPINAE}

1. Distal segment unisegmented P5 with only 2 long subequal setae/spines attached to rudimental leg, Th4 rarely with few long setules laterally, Bifidaeucyclopina group (possibly a new subfamily)...

- Distal segment P5 one-two segmented or fused to thoracal somite bearing 3 appendages of different length, Th4 always with group of long setules laterally, Trifidaeucyclopina group (possibly comprised two subfamilies) .... 4

2. Caudal rami more than 4 times as long as broad, Th4 smooth laterally ........... Stygocyclops Pleša, 1971 stat.n.

- Caudal rami shorter, about 2-3 times as long as broad, Th4 with group of tiny setules or few long hair-like setae laterally.....

3. P5 equipped with 2 long subequal setae, Th4 smooth or with tiny spines laterally; inner outgrowth of basipodite P4 round shaped ........ Defayeicyclops Alekseev et Vaillant, 2013 stat.n.

- P5 equipped with strong inner spine and weak seta 1.5 times as short as spine; Th4 with long setules laterally. ................................. Thaumasiocyclops Kiefer, 1930

4. P5 two-segmented ................... Macrocyclops Claus, 1893

- P5 one-segmented or the segment fused to th .................. 5

5. Antennule 17-segmented ..... Homocyclops Forbes, 1897

- Antennule with less number of segments; 12 or less ...... 6

6. P4 basipodite with triangular internal outgrowth .......... 7

- P4 with round shaped internal outgrowth .......................... 8

7. Caudal rami with very long lateral setae more than 2 times as long as ramus width .. Isocyclops Kiefer, 1957 stat.n.

- This seta as long as ramus width or shorter ..... Eucyclops Claus, 1893

8. Caudal rami at least 5.2 times as long as broad, P5 onesegmented with 2 setae and spine subequal in length ... Afrocyclops G.O. Sars, 1927

- Caudal rami usually shorter, spine in P5 usually shorter than setae ................................................................... 9

9. A1 long, reaching $3^{\text {rd }}$ free thoracal somite, receptaculum semini in uper part horn-like shaped.

Tropocyclops Kiefer, 1927

- A1 shorter, even not reaching distal edge of cephalothorax, receptaculum semini of different shape .............. 10

10. Caudal rami smooth, P5 with very short inner spine ..... Ochridacyclops Kiefer, 1937

- Caudal rami with one or several rows of spinules in dorsal surface

11. P5 fused to thoracal somite and represented with 3 spiniform setae, caudal rami very short (L/W less than 2, with 3 diagonal rows of spinules....

Ectocyclops Brady, 1904

- P5 more or less separated from thoracal somite and represented with one seta and two spines; caudal rami longer 
and with only one row of spinules

Paracyclops Claus, 1893

After separation of Stygocyclops and Isocyclops genera the genus Eucyclops was split into 9 subgenera on the construction of classical morphological features and microcharacters studied during serrulatus-group revision [Alekseev et al., 2006; Alekseev, Defaye, 2011].

The most important characters were as following: A1 segmentation; presence and type of hyaline membrane; basipodite antenna ornamentation, especially groups 1 and 2 presence (see Fig. 1); construction and ornamentation of $\mathrm{P} 4$ including coxal spine pinnation; P5 size, shape and armament; genital-double somite proportion; caudal rami shape, size, setae proportion, presence (absence) of lateral serra and hairs or spine presence on inner ventral and dorsal surfaces.

Hereafter a key for subgenera and description of the type for subgenera species as well as key for species of the world Eucyclops fauna are provided.

\section{KEY FOR SUBGENERA OF EUCYCLOPS}

1. Antennule 12 segmented

2. Caudal rami with hair-setae at inner surface ...................... Ciliocyclops subgen.n.

- Caudal rami without hairs on immer margin .................... 3

3. Caudal rami very short $(\mathrm{L} / \mathrm{W}<2.7)$. Breviramocyclops subgen.n.

- Caudal rami longer ( $\mathrm{L} / \mathrm{W}>2.7$, usually more than 3$)$...... 4

4. Distal setae of third endopodal segment of leg 4 long, extending above distal ends of nearest spines Subterrocyclops subgen. $\mathrm{n}$.

- Distal setae of third endopodal segment of leg 4 shorter, usually shorter than nearest spine or sometime only outer seta can reach distal end of next spine

5. Antennule with denticulate hyaline membrane at distal segments, caudal rami with saw

Denticylops subgen.n.

- Antennule with smooth hyaline membrane or without it; if not then caudal rami smooth or P5 inner spine clearly shorter than segment; caudal rami with serra or not ... 6

6. Caudal rami with more or less developed spinal row extending along outer edge

- Caudal rami smooth with only few spinules near setae insertated places, leg 5 with weak inner spine ................. Macrurocyclops subgen.n.

7. Leg 5 with very small inner spine, shorter that leg length and about half of outer seta ....... Sarsicyclops subgen.n.

- Leg 5 with larger inner spine, longer that leg length and about half of outer

8. Basis of antenna on caudal surface with 1-2 groups of hair-setae in distal-lateral positions (groups $1 \& 2$ ) ...... Eucyclops subgen.n.

- This segment without hair-setae rows on caudal surface of antennal basis ....................... Speratocyclops subgen.n.

\section{Eucyclops (Eucyclops) subgen.n.}

Type species: Eucyclops serrulatus Fischer, 1851.

Small and avarage size cyclopids $650-1150 \mu \mathrm{m}$ without caudal rami seta. Antennula 12-segmented, last 3 segments with narrow or wide smooth hyaline membrane usually reaching to distal edge of cephalotorax. A2 basipodite on posteri- or side with 1-2 groups of hair-setae in distal-lateral positions. Genital double-somite as long as wide, caudal rami of average size (3.5-6.5, rarely up to 8 times as long as broad). Swimming legs spine formula $3 / 4 / 4 / 3$. Distal segment endopodite P4 about 2 times as long as wide, distal seta of the segment never reach distal ends of nearest spines. P5 with inner spine strong, shorter than middle seta, at least 1.5 times as long as segment itself and usually about as long as outer setae or longer. Caudal rami with more or less long lateral saw and don't covered with hairs or dents on inner edge or inner/ventral surfaces. Males always smaller than females with P5 construction and armament like in females, P6 usually with strong inner spine, caudal rami shorter than in female. Subgenus includes more than 28 species and 10 subspecies.

\section{Eucyclops serrulatus Fischer, 1851}

Fig. 5.

FEMALE. Body color rusty brown, rarely dark brown or greyish. Full length without caudal seta from 800 to 1700 $\mu \mathrm{m}$. Cephalosome as long as wide, maximum width close to posterior margin. Last somite of prosome with lateral group of short setules. Genital double somite 0.7-1.2 times as long as wide. Caudal rami 3.5-6.5 times as long as wide, with longitudinal row of spinules along most of outer edge of each ramus, but partly reduced in some taxa inhabiting subterranean or spring environments and never with hair-like setae or denticles on dorsal or ventral surfaces. Six setae inserted on distal part of ramus. Dorsal seta about half the length of innermost terminal seta (VI), covered with long setules on both sides; outermost seta (III): a spiny seta with dense setules on both sides, but longer on inner margin, about 3 times as long as dorsal seta yet distinctly shorter than seta VI. Antennule 12-segmented, with smooth membrane along 3 distal segments. Posterior side of antenna (A2) basipodite (see Fig. 1A): apical group N1 with 2-6 long setules and group N2 with variable number of the same setules $(0-4)$ subdistally along inner margin; with three oblique and parallel rows of spinules (N3-5) and 2 groups of marginal spinules (N17) and (N15). Anterior side of basipodite A2 (see Fig. 1B): 3-5 strong spinules, of different length among species, subdistally (N8), groups 9 and 10 sometimes united in one row; a long row of 10-17 spinules medially $(\mathrm{N} 11+\mathrm{N} 12)$; N13 and N14 represented by 2 isolated groups of tiny spinules; groups 15 and 17 usually composed of long spinules and group 16 of short or even tiny denticles.

Setae on all segments of P1-P4 uniformly seta-like, not constricted, flanked with series of long setules on both edges. The setules at least twice as long as the distance between them. Inner edge of basipodite of P1-P4 usually with group of long setules. Intercoxal plate of P1 with two protuberances, a transversal row of small denticles around midway, and two groups of thin spinules on main body of protuberances, not extending beyond their edges. Intercoxal plates of P2$\mathrm{P} 3$ also with protuberances on free edge and with groups of setules. Distal segment of Enp P4 elongated, 2.2-2.8 times as long as wide, with 2 strong apical spines; inner spine $1.2-$ 1.5 times as long as outer spine. Coxopodite of P4 with strong inner spine, dense hair-setae on inner side, and in many taxa with large gap among short hair-like setae on inner side. Posterior side of coxopodite with tiny spinules on inner side not organized in groups, and groups of spinules and setules, giving the formula A-B-C+D-E-H (see Fig. 1C). Intercoxal plate of $\mathrm{P} 4$ with protuberances wide but not pro- 


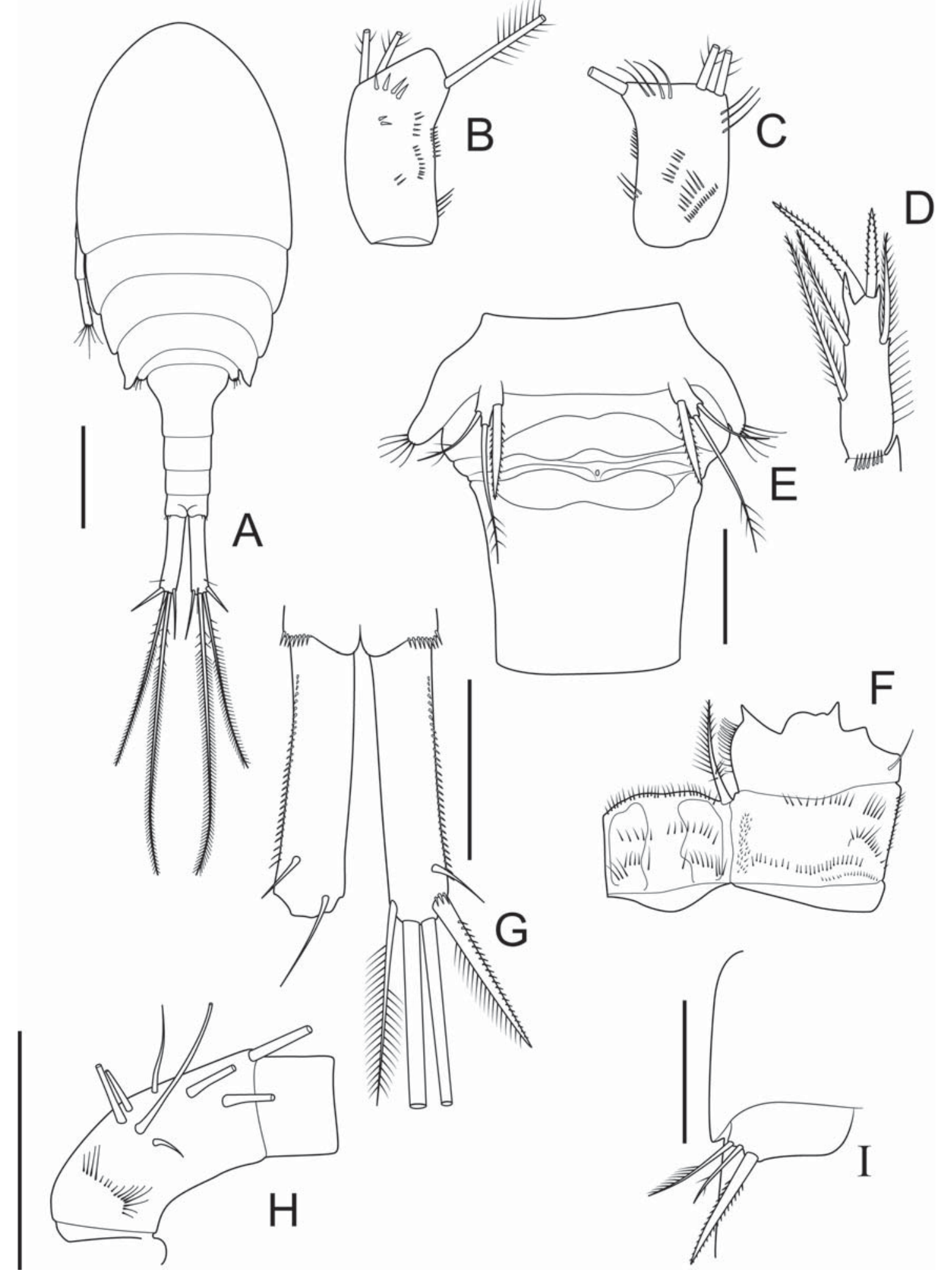

Fig. 5. Eucyclops serrulatus (Fischer, 1851): A - habitus, dorsal; B - A2 basipodite, anterior; C - basipodite of A2, posterior; D distal segment of endopodite P4; E - genital segment and P5, ventral; F — coxa and coupler of P4; G — caudal rami, dorsal; H - first segment of A1; I - P6, O'. Scale bars: A $-75 \mu \mathrm{m} ; \mathrm{E}, \mathrm{H}, \mathrm{I}-50 \mu \mathrm{m} ; \mathrm{G}-40 \mu \mathrm{m}$. Orig.

Рис. 5. Eucyclops serrulatus (Fischer, 1851): А - общий вид, дорсально; В - базиподит А2, спереди; С - базиподит А2, сзади; $\mathrm{D}$ - дистальный членик эндоподита Р4; Е - генитальный сегмент и Р5, вентрально; F — соединительная пластинка и коксопо-

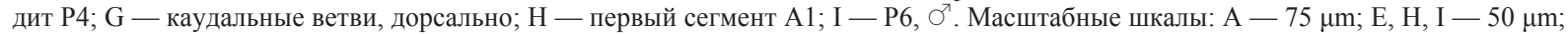
$\mathrm{G}-40 \mu \mathrm{m}$. Ориг. 
truding beyond free edge of plate; group of hair-like, long setules along edge, 2 groups of setules and spinules on main body of plate. P5 1-segmented, with wide and strong inner spine, and 2 setae; outer seta subequal in length to spine, middle seta about 1.1-2 times as long as spine.

MALE. Body length $650-1100 \mu \mathrm{m}$. Cephalosome 1.11.5 times as long as wide, with maximal width near to its posterior end. Last somite of prosome smooth, last urosomal somite with a row of denticles on caudal side. Caudal rami 3.8-5 times as long as wide, without lateral spinules. Slender innermost terminal seta (VI) about twice the length of spine-like outermost seta (III). Lateral seta (II) shifted to dorsal side, with several spinules at base. Dorsal seta (VII) near insertion of innermost seta (VI), about 0.8 times as long as outermost seta. Antennule 14-segmented. Antennary basipodite basically as in female, with 4-6 long setules posteriorly corresponding to groups N1 and N2; anteriorly with 3 rows of strong spinules and an additional row of spinules subdistally. Coxopodites and intercoxal plates of P1-3 with apical setules. Inner edge of basipodite of P4 with short setules. Coxopodite of P4 with strong spine, bearing 8-10 stiff inner hair-like setae and 2-3 hair-like setae at apex and 1 at base of spine, so also with a gap in those setae at the outer margin. Also coxopodite of P4 has a narrow row of small spinules on its inner side and several groups of spinules (corresponding to A-B-C+D-F) posteriorly (see Fig. 1C). Intercoxal plate of $\mathrm{P} 4$ with small protuberances, strong hairlike setae on free edge, and 3 groups of setules on both sides. Distal segment of endopodite of P4 about 2.2-3.2 times as long as wide, with inner spine as long as segment and always longer than outer spine. P5 with inner spine slightly shorter than in female, outer seta as long as spine, middle seta significantly longer than spine. P6 with inner spine and two setae with variable length proportions.

There appeared to be appreciable variation among the specimens from the locus typicus as well as in other populations of the species and in other species of the serrulatusgroup. We identified three morphotypes, based on the type population (E. serrulatus s.str.) from St. Petersburg [Alekseev et al., 2006]. Type A, with plumose setae on the endopodite and exopodite segments of P1-P4, and innermost and outermost setae of the caudal rami with dense long setules. Intercoxal plate of $\mathrm{P} 4$ with dense long setules, sometimes as long as half of the plate's width. At some distance from seta I, the setules are much longer than the distance between them. Type B, with a few short setules on caudal setae III and VI; characterized by a reduction in length of the setules of the exopodal and endopodal setae of P4, and also of the setae of the caudal rami. Distal half of setae of Enp3P4 and most setae of Exp3P4 blade-shaped, narrowed, and with much shorter setules on distal part than on proximal part. Intercoxal plate of $\mathrm{P} 4$ with short marginal setules of about 1/ 3 or less the membrane width. Type $\mathbf{C}$ (pitted form). In the caudal setae, a configuration similar to that of form $\mathrm{A}$ is found, but this form is provided with a pitted integument on the cephalosome, urosome, caudal rami, and first antennae. In the Peterhoff ponds, Type $\mathrm{C}$ was rare during spring $(15 \%)$ but became more frequent in fall $(40 \%)$. Types A and B were most abundant in spring (about $40 \%$ each), hybrids between these three types dominated during summer and fall. The specimens of these three groups can live together at the same time in the same waterbody and easily hybridize in both laboratory experiments and in the field. The possible reasons for the coexistence of these types had been discussed in Alekseev et al. [2006].
Hereafter a key for valid species of subgenus is provided.

Key to subgenus EUCYCLOPS (EUCYCLOPS) SPECIES AND SUBSPECIES

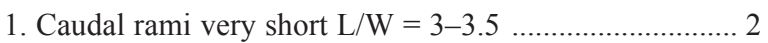

- Caudal rami more than 3.5 times as long as wide ........... 3

2. Dorsal caudal seta longer than outermost seta .................. E. (E.) bondi Kiefer, 1934 [Haiti, Americas]

- Dorsal caudal seta shorter than outermost seta

E. (E.) conrowae Reid, 1992 [Americas]

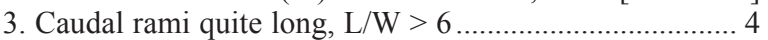

- Caudal rami of moderate length, 3.6-6 times as long as 9

4. Caudal rami serra extending along less than third of ramus length.

- Caudal rami serra extending along at least half of ramus length .....

5. Basipodite of A2 on caudal surface with 2 groups of long hair-setae $(1,2)$ and with one group of hair-seta on frontal surface ........E. (E.) neumani (Pesta, 1927) s.lat.

[Central and South America]

- Basipodite of A2 on caudal surface with one group of long hair-setae (1) and without such armament on frontal surface ........................... E. (E.) titicacae Kiefer, 1957 [partly, for females with smooth hyaline membrane in A1; possibly endemic of lake Titicaca]

6. Caudal rami serra extending along practically whole rami length (exception - underground populations), coxal spine of P4 on outer edge with clearly seen gap in hairsetae or even almost without hair-setae, smouth maxilar palp edge with full line of hair-setae, maxilar palp with group of small dents .................. E. (E.) pacificus Ishida, 2000

[SEA, Pacific coast rivers]

7. Caudal rami very long, $\mathrm{L} / \mathrm{W}=6.5-8$; $\mathrm{P} 5$ inner spine $1.5-2$ times as long as outer setae; in P4 connective plate of coxa along external margin with strong hair-setae ...... 8

- Caudal rami usually shorter but sometimes with L/W up to 7 , inner spine of P5 less than 1.25 times as long as outer setae; in P4 connective plate of coxa along external margin with very fine hair-setae .

E. (E.) serrulatus (Fischer, 1851)

[populations of cold season,

in high latitudes and altitudes]

8. Caudal rami $\mathrm{L} / \mathrm{W}=7-8$, caudal dorsal seta shorter or less than 1.1 times as long as outermost seta; medial seta of P5 1.3-1.5 times as long as inner spine...

E. (E.) elegans (Herrick, 1884)

[America]

- Caudal rami L/W less than 7 (about 6.5), caudal dorsal seta at least 1.35 times as long as outermost seta; P5 medial seta twice as long as inner spine

E. (E.) solitarius Herbst, 1959

[South America, Brazil]

9. Hyaline plate of distal segments A1 usually very wide, about one third of segment width; P4 coxal spine homogeneously covered with quite long rare hair-seta; P5 inner spine about as long as outer seta; anal plate with double wrinkle at distal edge

E. (E.) agiloides (Sars, 1909) s.lat. with 3 subspecies: $E$. (E.) a. a. (Sars, 1909),

E. (E.) a. roseus Ishida, 1997,

E. (E.) a. miracleae Alekseev, 2010

[Moderate and tropic climate zones of the Old World] 
- Combination of the characters different 10

10. Caudal rami with long serra practically along all rami length.....

- Caudal rami with more or less reduced serra, coxal spine of P4 on outer edge with full line of hair-setae, maxilar palp with group of small dents ................................ 27

11. Innermost caudal seta very short, shorter than dorsal seta and about as long as outermost seta; outermost caudal spine-like seta perpendicularly joined to ramus .....

E. (E.) acanthoides (Van Douwe, 1914)

[Tropical Africa]

- Innermost caudal seta longer; outermost caudal seta not joined perpendicularly to ramus.....

12. Innermost caudal seta short, subequal or not more than 1.2 times as long as outermost seta; if longer then P5 with inner spine longer than outer seta ...................... 13

- Innermost caudal seta usually more than 1.2 times as long as outermost seta; if shorter then P5 with inner spine equal or longer than outer seta .................................. 18

13.P5 inner spine longer or equal to outer seta; P4 Enp with distal outer spine as long as segment itself; caudal rami with very long (sometimes up to half of caudal rami width) spines on outer edge.

- P5 inner spine shorter than outer seta; P4 Enp with distal outer spine shorter than segment itself; caudal rami with moderate or short spines on outer edge .................... 15

14. P4 Enp with subequal spines; P5 inner spine as long as outer seta

E. (E.) vandouwei Brehm, 1909 [Tropical Africa]

- P4 Enp with inner spine significantly longer than outer spine; P5 inner spine longer than outer seta .....

E. (E.) albuferensis Alekseev, 2008 [Spain]

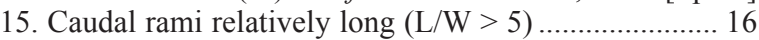

- Caudal rami usually shorter ............................................. 17

16. P4 Enp distal setae long and almost reaching ends of distal spines; caudal rami about 5-6 times as long as wide ......... E. (E.) extensis Hsiao, 1950 comb.n. [China]

-These setae reaching only the middle of distal spines; caudal rami more than 6 times as long as wide

E. (E.) procerus Dussart, 1981 [Africa]

17.Inner medial caudal seta about two times as long as outer medial seta

E. (E.) ensifer Kiefer, 1936

[Central and South America]

- Inner medial caudal seta 2.5 times and more as long as outer medial seta ........ E. (E.) pectinifer (Cragin, 1883)

[Northern America]

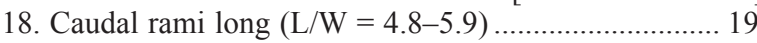

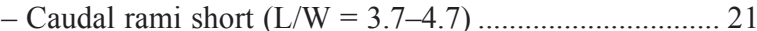

19. P5 outer seta very long, practically equal to medial seta and about twice of inner spine; caudal saw with very small and equal in size lateral spines .................... E. (E.) spatulatus Morton, 1990 [Australia]
outer seta clearly shorter than medial seta and about as long as inner spine; caudal saw with relatively large and different in size lateral spines ..................................... 20

20 . Outermost caudal seta elongated and about $2 / 3$ of ramus length; lateral caudal seta twice of ramus width .

E. (E.) demacedoi Lindberg, 1957 [Chili]

Outermost caudal seta not more than half of ramus length; lateral caudal seta not longer than ramus width, coxal spine of P4 on external edge always with gap among strong hair-setae ...... E. (E.) serrulatus (Fischer, 1851) [Populations of cold season in low-lands and moderate climate or warm season in Arctic and in mountains]

21. Innermost caudal seta not less than $1.2-1.5$ as long as outermost seta
- Innermost caudal seta less than 1.2 as long as outermost seta or equal to it ....................................................... 23

22. Caudal rami parallel; dorsal seta about as long as outermost seta.

E. (E.) australensis Morton, 1990 [Australia]

Caudal rami divergent; dorsal seta about half of outermost seta; $\mathrm{P} 4$ coxal spine external edge always with gap among strong hairs ................... (E.) serrulatus (Fischer, 1851) [Populations of warm season in moderate and southern climate zones in Palearctic and in some enclaves]

23.P4 Enp distal spines about similar length (not more than 1.2 times difference); $\mathrm{P} 5$ inner spine about half of outer seta .....E. (E.) silvestrii (Brian, 1927) [South America]

-P4 Enp with inner distal spine 1.3-1.5 as long as outer one; inner spine of $\mathrm{P} 5$ variable length

24. P5 inner spine at least two times as short as outer seta.

.

- This spine equal or longer than outer seta ..................... 26

25.P5 inner spine at about three times as short as outer seta and practically equal to segment length ...

E. (E.) cuatrocienegas Suárez-Morales et Walsh, 2009

[Mexico]

-This spine about two times as short as outer seta and clearly longer than segment...E. chilensis Löffler, 1963 [Chile]

26. Dorsal caudal seta longer or equal to innermost seta; P4 Enp outer distal seta about reaching distal tip of nearest spine ........ E. (E.) ariguanabensis Brehm, 1949 [Cuba]

- Dorsal caudal seta clearly shorter than innermost seta; P4 Enp outer distal seta reaching to the middle of nearest spine; A1 short, not reaching distal end of cephalothorax E. (E.) prionophorus Kiefer, 1931 [America]

27. Caudal rami with very short serra occupying less than half of outer edge ..................................................... 28

-Caudal rami serra occupies not less than half of outer edge .. 33

28.In P4 Enp with inner distal spine as long as segment itself

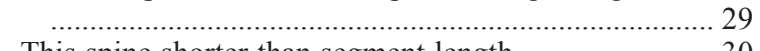

This spine shorter than segment length ...mend

29. P5 inner spine as long as outer seta and about $2 / 3$ of medial seta

E. (E.) alticola Kiefer, 1957 [South America]

-P5 inner spine about half of outer seta and as short as half of medial seta ...E. (E.) farsicus Lindberg, 1941 [India]

30. Innermost caudal seta twice of outermost seta .......... 31

- Innermost caudal seta 1.5 times or less as long as outermost seta.....

31. P4 Enp inner and outer setae reaching distal tips of spines.

.....E. (E.) ruttneri Kiefer, 1933 s.lat. [Japan, Oceania]

- These setae significantly shorter and never reaching distal tips of adjacent spines

E. (E.) defectus Lindberg, 1937 [Switzerland]

32. P5 inner spine strong, knife-shaped, about as long as medial seta; caudal rami with parallel and relatively short branches $(\mathrm{L} / \mathrm{W}<4)$ E. (E.) hadjebensis (Kiefer, 1926)

[Morocco, North Africa]

- P5 inner spine shorter, caudal rami divergent .............. 33

33. Innermost caudal seta shorter than outermost seta .........

E. (E.) romaniensis Alekseev, 2010

- Innermost caudal seta equal or longer than outermost seta

34. P5 inner spine relatively long as long as outer setae 34

35

- P5 inner spine shorter

36

35.Caudal rami at external edge with more or less long serra 


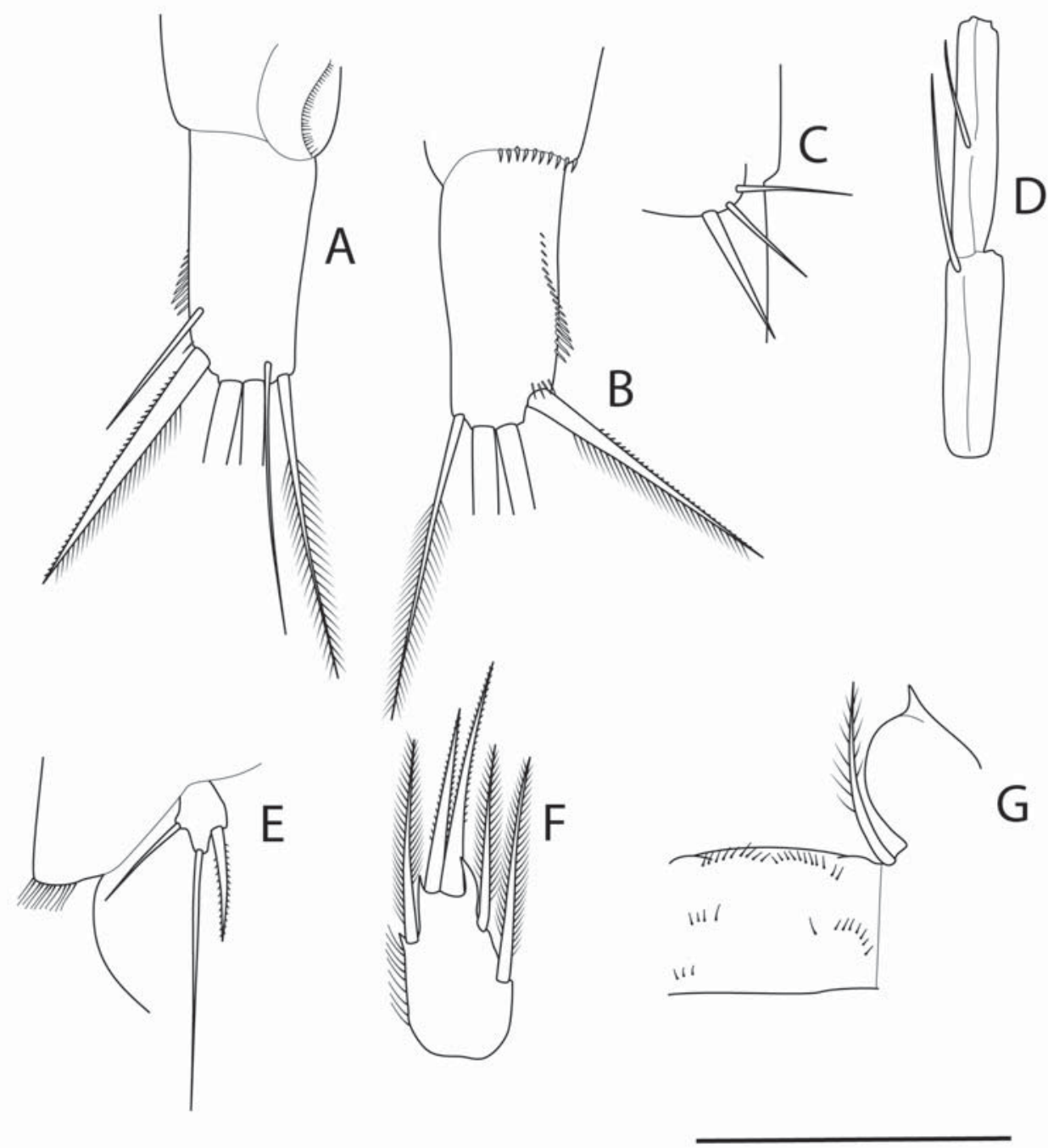

Fig. 6. Eucyclops (Breviramocyclops) breviramatus Löffler, 1963: A — caudal ramus, dorsal; B — caudal ramus, ventral; C - P6, O'; D — distal segments of A1; E — P5; F — distal segment of endopodite P4; G — intercoxal plate of P4. Scale bar: $100 \mu \mathrm{m}$. Redrawn after Löffler [1963].

Pис. 6. Eucyclops (Breviramocyclops) breviramatus Löffler, 1963: А - каудальная ветвь, дорсально; В - каудальная ветвь, вентрально; С - P6, О7; D - дистальные сегменты А1; Е - P5; F - дистальный сегмент эндоподиты P4; G - соединительная пластинка P4. Масштабные шкалы: $100 \mu \mathrm{m}$. Вопсроизведено по Löffler [1963].

(about 2/3 ramus length); dorsal seta very short, less than half of outermost seta

..... E. (E.) agiloides azorensis Defaye et Dussart, 1991

[Azores]

-Caudal rami at external edge with short serra (less than $1 / 2$ ramus length); dorsal seta about as long as outermost seta .................... E. (E.) permixtus Kiefer, 1929 [Java]

36. Caudal rami more or less long $(\mathrm{L} / \mathrm{W}>4.5)$ with very small spine on external edge ... 37

- Caudal rami short $(\mathrm{L} / \mathrm{W}<4.5)$ with spine of normal size

37. P4 Enp with outer distal seta very short and not extending above the end of the segment; innermost caudal seta as long as outermost seta

E. (E.) parvicornis Harding, 1942 [East Africa]

-.P4 Enp with outer distal seta much longer and extending up to the middle of distal adjacent spine; innermost caudal seta at least 1.15 times as long as outermost seta .......E. (E.) serrulatus tsushimensis Ishida, 2001 stat.n.

Several other species described by Ischida (E. ohtakai Ishida, 2000, E. borealis Ishida, 2001) are very doubtful and possibly reperesent seasonal variation of E. serrulatus, but for sure they do not belong to speratus-group as was suggested by author. Taxonomical position of them øû not clear.

\section{Eucyclops (Breviramocyclops) subgen.n.}

Type species: Eucyclops breviramatus Löffler, 1963.

Small and average size cyclopids with body length without caudal seta about 800-1200 $\mu \mathrm{m}$ inhabiting mainly marsh habitats. Body colour brown or brown-yellowish. Antennule 
Fig. 7. Eucyclops (Ciliocyclops) ciliatus (Sars, 1909): A habitus, dorsal; B - caudal ramus, dorsal. Scale bar: $200 \mu \mathrm{m}$. Redrawn from Sars, 1909.

Рис. 7. Eucyclops (Ciliocyclops) ciliatus (Sars, 1909): A общий вид, дорсально; В - каудальная ветвь, дорсально. Масштабная шкала: 200 m. Воспроизведено по Sars, 1909. 12-segmented, reaching the distal edge of first free somite, three distal segments with smooth hyaline membrane. Swimming leg exopodite spinal formula 3/4/4/3. Rudimental P5 with quite long seta and strong inner spine. Caudal rami very short, $\mathrm{L} / \mathrm{W}$ ratio less than 3 .

\section{Eucyclops (Breviramocyclops) breviramatus Löffler, 1963 \\ Fig. 6.}

FEMALE. Body length $1163 \mu \mathrm{m}$. Genital double-somite slightly wider than long. Caudal rami very short, L/W ratio 2.5 (2.3-2.6). Outermost caudal seta about as long as ramus length. Caudal rami laterally with a short saw occupied about half of ramus length. Distal four spines of saw significally longer than others. Dorsal seta subequal to outermost seta. Innermost seta significally longer than outermost seta (1.6-1.8). Swimming legs exopodite spinal formula 3/4/4/3. Distal segment endopodite P4 1.5 times as long as wide. Distal spines of the segment ratio: inner/outer 1.2; inner spine to segment ratio 1.4-1.5. Rudimental P5 about 1.3 times as long as wide, inner spine longer than segment itself

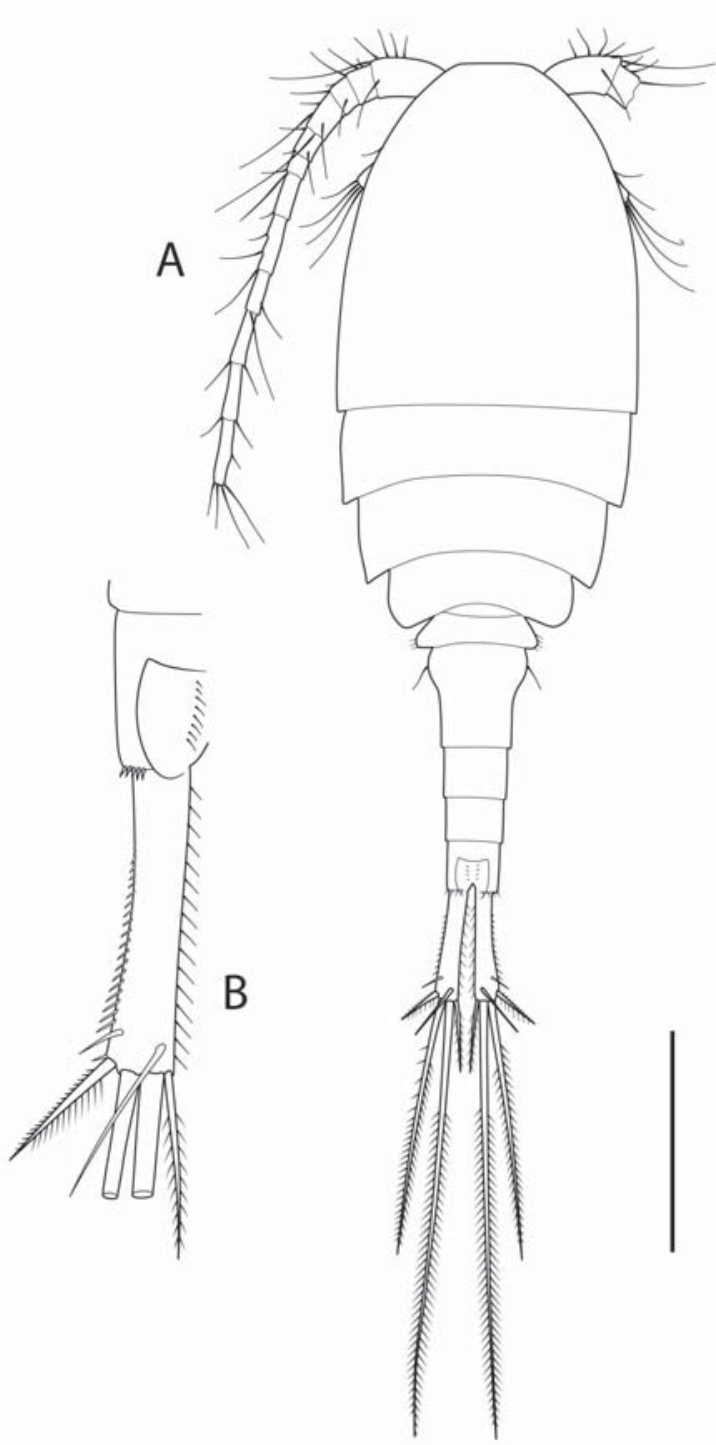

but shorter than both setae, length of armaments beginning from spine 27-34/68-85/34-39 $(\mu \mathrm{m})$.

MALE. Body length $980 \mu \mathrm{m}$. Caudal rami significally shorter than in female, without serra laterally, but with several small spines near lateral and outermost seta insertation place. P4 and P5 similar to female. Rudimental P6 with inner spine about as long as second abdominal segment and just a little longer than two other setae.

Key to subgenus EUCYCLOPS (BREVIRAMOCYCLOPS) SPECIES

1. Caudal rami very short $(\mathrm{L} / \mathrm{W}<2)$

E.(B.) edytae Tang et Knott, 2009 [Caves in Australia]

- Caudal rami longer $(\mathrm{L} / \mathrm{W}>2)$

2. Innermost seta more than twice as long as outermost seta E.(B.) puteincola Kiefer, 1982 [wells in Syria]

- Innermost seta less than twice as long as outermost seta . 3

3. Inner weak spine of P5 about as long as segment length and at least 3 times shorter than outer seta

E. (B.) siolii Herbst, 1962 [Brazil] 


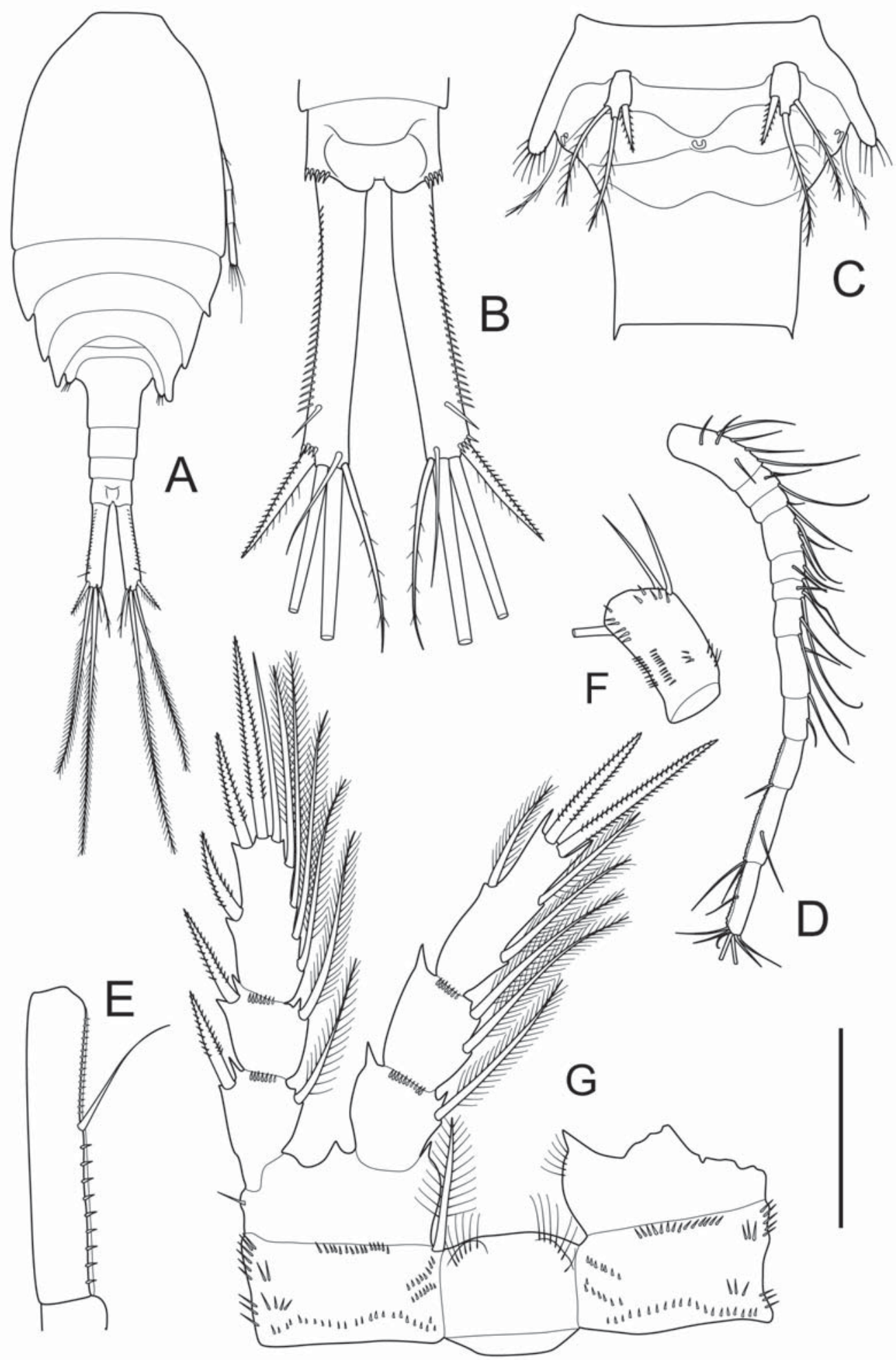

Fig. 8. Eucyclops (Denticylops) denticulatus (Graeter, 1903): A - habitus, dorsal; B - caudal rami, dorsal; C - genital segment and P5, ventral; D - A1; E - distal segment of A1; F — basipodite of A2, anterior; G - P4. Scale bars: A - $400 \mu \mathrm{m} ; \mathrm{B}, \mathrm{C}-120 \mu \mathrm{m}$; D $200 \mu \mathrm{m} ; \mathrm{E}-50 \mu \mathrm{m} ; \mathrm{F}, \mathrm{G}-100 \mu \mathrm{m}$. Orig.

Рис. 8. Eucyclops (Denticylops) denticulatus (Graeter, 1903): А — общий вид, дорсально; В — каудальные ветви, дорсально; С генитальный сегмент и Р5, вентрально; D - A1; Е - дистальный сегмент A1; F - базиподит А2, вид спереди; G - P4. Масштабные шкалы: А $-400 \mu \mathrm{m} ; \mathrm{B}, \mathrm{C}-120 \mu \mathrm{m} ; \mathrm{D}-200 \mu \mathrm{m}$; E $-50 \mu \mathrm{m} ; \mathrm{F}, \mathrm{G}-100 \mu \mathrm{m}$. Ориг. 
- This spine twice as long as segment and nearly equal to outer seta in length.... E. (B.) breviramatus Löffler, 1963 [Ecuador]

\section{Eucyclops (Ciliocyclops) subgen.n.}

Type species: Eucyclops ciliatus (G.O. Sars, 1909).

Small size Eucyclops inhabiting tropical areas. Caudal rami with hairs on inner/dorsal surfaces. Antennule relatively long reaching second free somite with narrow smooth hyaline membrane or without it at all. Caudal rami 5 times and more as long as broad with long lateral serra consisting of small spines. Innermost seta clearly longer than outermost seta. Distal seta of endopodite P4 not reaching distal end of nearest spine. Rudimental P5 with small and weak inner spine close in length to segment itself or even smaller.

\section{Eucyclops (Ciliocyclops) ciliatus (G.O. Sars, 1909)} Fig. 7.

FEMALE. Body length $860 \mu \mathrm{m}$. Antennule reaching second free somite without or with invisible hyaline membrane on three distal segments. Last thoracal somite with rare hair-like seta laterally. Genital double somite slightly longer than wide. Caudal rami slightly divergent, 5 times and more as long as wide. Distal caudal seta ratio beginning from outermost: 1:5.7:9.7:1.6; dorsal seta slightly longer than outermost seta; lateral seta as long as ramus width. Rudimental P5 with very short and weak inner spine about as long as segment itself or even less.

MALE. Not known.

\section{Key to SUbGenus EUCYCLOPS (CILIOCYCLOPS) SPECIES}

1. Caudal rami with short and rare hair-setae only on proximal/inner edge and with very short lateral serra (about third of caudal length) produced by tiny denticles ........ E. (C.) neotropicus Kiefer, 1936 [South America, Brazil]

- Caudal rami more or less homogeneously plumose and with better developed lateral serra (half of caudal length or more) produced by strong denticles .......................... 2

2. Caudal rami long, $\mathrm{L} / \mathrm{W}>5$. E. (C.) ciliatus (Sars, 1909) [Tanganyika]

- Caudal rami shorter, $\mathrm{L} / \mathrm{W}<5$.

3. Innermost caudal seta about 2 times as long as our seta, lateral serra about half of caudal length E. (C.) rarispinus (Sars, 1909) [Tanganyika] -Innermost caudal seta about 1.1-1.5 times as long as outermost seta, serra extending along practically whole outer margin ..........E. (C.) subciliatus Dussart, 1984 [Brazil]

\section{Eucyclops (Denticylops) subgen.n.}

Type species: Eucyclops denticulatus Graeter, 1903.

Female of moderate length, caudal rami of different proportion but always length/wide ratio more than 3.5. Innermost seta usually significally longer than outermost seta. Outermost seta in several species inserted at some distance from other distal caudal seta. Inner surface of caudal rami smooth, lateral edge usually with long saw produced with dents of large size. Antennule 12-segmented, relatively long, 1-3 distal segments with clear seen serrated hyaline membrane. Distal setae of endopodite P4 never extend beyond distal tips of nearest spine. Rudimental P5 with inner spine of different lengths, but always strong and at least 1.5 wider than middle seta width and as long as segment itself.

\section{Eucyclops (Denticylops) denticulatus Graeter, 1903} Fig. 8.

FEMALE. Length 900-1230 $\mu \mathrm{m}$. Cephalotorax as long as wide, last thoracal somite with long dense setae lateraly. Genital double somite about as long as wide with receptaculum semini of typical for genus shape. Caudal rami 6-8 times as long as wide, clearly divergent, lateral edge with conspicuous lateral serra, extending nearly to base. Innermost outer seta 1.5-2 times as long as outer spine-like seta and nearly as long as ramus or shorter. Caudal setae ratio beginning from outermost: 1.0:5.0:7.1:1.3. Dorsal seta longer than outermost seta but shorter than innermost seta. Lateral seta small and weak, not longer than ramus width. Antennule 12-segmented reaching to the middle of first free somite. Three last segments with clearly serrated hyaline membrane. First segment with membrane serrated by different way, distal part with small denticles, proximal part with 8-12 large denticles. Antenna basipodite ornamentation as in Figure 5. Swimming legs P1-P4 3-segmented, Exp distal spines formula 3/4/4/3. P4 Enp three times as long as wide, inner apical spine nearly as long as Enp 3, and about 1.5 times as long as outer. Distal setae just reaching of the middle of nearest spines. P5 inner spine much shorter than outer seta, and more slender than in $C$. (D.) macruroides - the nearest congender. Spine-setae ratio beginning from the spine: 1.0:2.5:2.1. Spine slightly longer than segment length.

MALE. Significantly shorter than female with shorter caudal rami. P4 and P5 construction similar to female. P6 with strong inner spine and 2 short and weak setae.

\section{Key to subgenus EuCyCLOPS (DENTICyCLOPS) SPECIES AND} SUBSPECIES

1. Caudal rami long, $\mathrm{L} / \mathrm{W}>5.5$ 2

- Caudal rami less than 5.5 times as long as wide .............. 6

2. Inner spine of P5 longer than outer seta ....................... 3

- This spine noticeably shorter than outer seta .................. 4

3. Inner spine of P5 wide, knife-like, caudal rami 6-8 times as long as wide, only the first distal segment of antennule with serrated hyaline plate in proximal part .......... ...... E. (D.) neomacruroides Dussart et Fernando 1990

[North America]

- Inner spine of P5 thin, seta-like, caudal rami 4-6 times as long as wide, three distal segments of antennule with serrated hyaline plate....

$$
\text { E. (D.) longispinosus Pesce et Galassi } 1987
$$

[Caves in Italy]

4. Caudal rami with reduced saw (5-9 short spines) ........... E. (D.) titicacae Kiefer, 1957 [partly, for females with serrated hyaline membrane in A1; endemic of lake Titicaca]

- Caudal rami with row of denticles along outer margin .. 5

5. Caudal rami 7-9 times as long as wide, the first distal segment of antennule in proximal part with fine serrated hyaline plate (20-25 tiny denticles) .

E. (D.) macruroides Lilljeborg, 1901 [Palearctic]

- Caudal rami 5-7 times as long as wide, the first distal segment of antennule in proximal part with ruffle serrated hyaline plate (10-18 relatively large denticles)

E. (D.) denticulatus (Graeter, 1903) [Palearctic] 

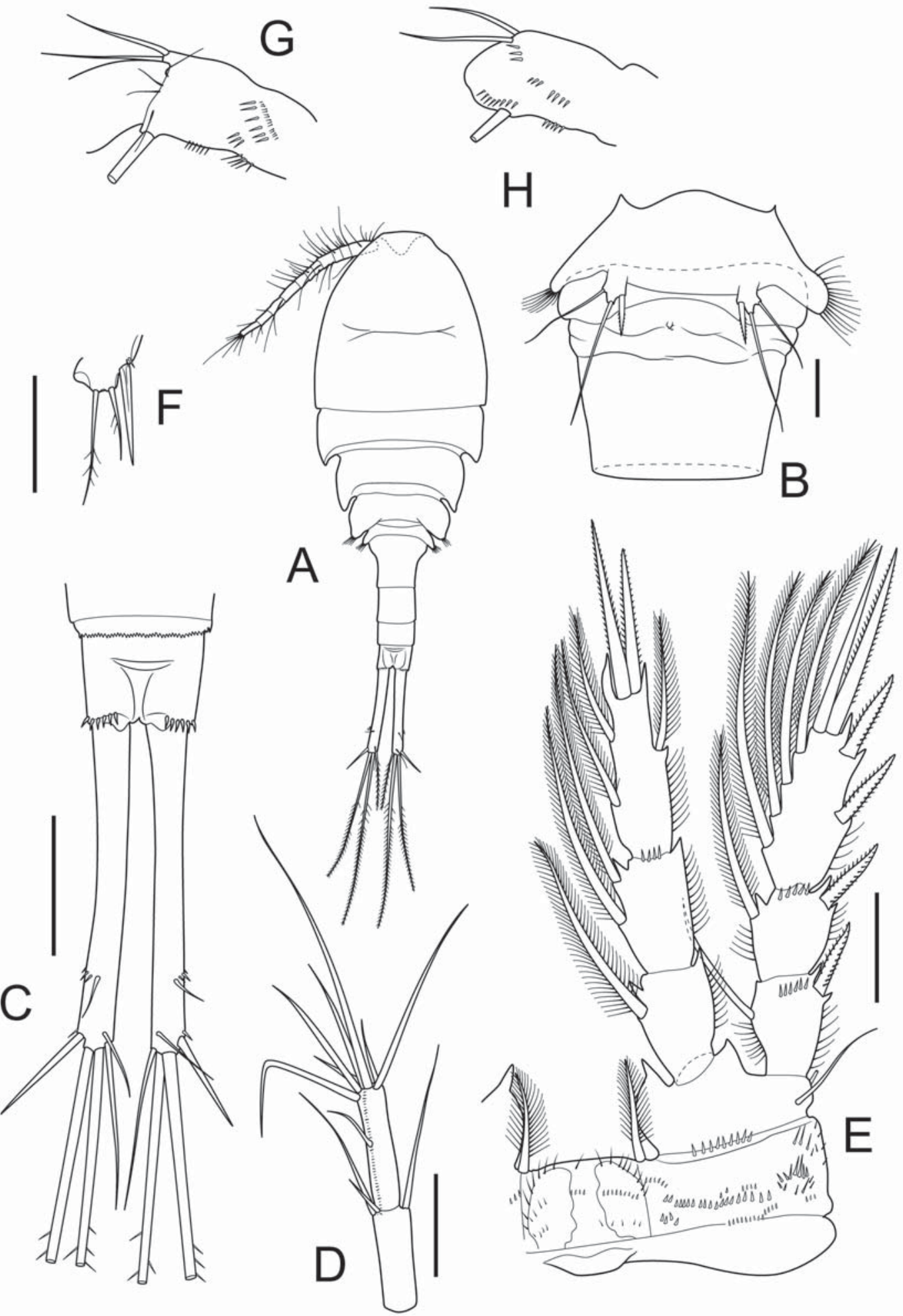

Fig. 9. Eucyclops (Macrurocyclops) macrurus (Sars, 1863): A — habitus, dorsal; B — genital segment and P5, ventral; C - caudal rami, dorsal; D - distal segments of A1; E - P4; F - P6, O'; G - basipodite of A2, posterior; H - basipodite of A2, anterior. Scale bars: B, F $-30 \mu \mathrm{m}$; D, E - $50 \mu \mathrm{m}$; C $-100 \mu \mathrm{m}$. P6, O redrawn from Gurney, 1931, others - orig.

Pис. 9. Eucyclops (Macrurocyclops) macrurus (Sars, 1863): А - общий вид, дорсально; В - генитальный сегмент и Р5, вентрально; С - каудальные ветви, дорсально; D - дистальные членики А1; Е - P4; F - P6, О' G - базиподит А2, вид сзади;

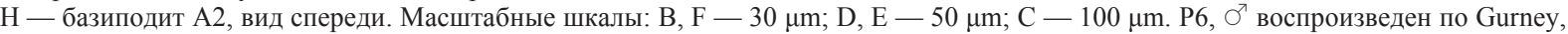
1931, остальные - ориг. 
6.Inner spine of P5 short, nearly equal to segment length, if not then not less than twice shorter than outer seta; innermost caudal seta inserted above other setae E. (D.) euacanthus (Sars, 1909) s.lat. 7 [Pantropical, Japan, Kamchatka]

-Inner spine of P5 longer than segment length and not more than 1.5 times shorter than outer seta; innermost caudal seta inserted at the same level as other setae .............. 11

7. Outermost caudal seta naked or with external row produced by tiny spines ........................................................ 8

- This seta pinnate at least at inner side ............................. 10

8.Caudal rami with row of strong denticles along practically whole outer margin

E. (D.) euacanthus euacanthus (Sars, 1909)

[Africa, SEA, Kamchatka, Japan, Australia]

- Caudal rami with markedly reduced row of denticles .... 9

9. Lateral row of denticles hardly reaching to the middle of caudal rami

E. (D.) eucanthus cognatus Kiefer, 1928

[Caves in SAR]

- Lateral row of denticles reaching to the upper third of caudal rami margin

$$
\text { E. (D.) eucanthus lanceolatus Dussart, } 1974
$$

[Ethiopia]

10. Inner spine of P5 short, nearly equal to segment length and about 4 times shorter than outer seta; dorsal caudal seta nearly 1.5 times as long as outermost seta ...

E. (D.) eucanthus baylyi Morton 1990 [Australia]

- This spine nearly twice as long as segment and 2 times shorter than outer seta; innermost caudal seta inserted as other setae, dorsal caudal seta shorter.

E. (D.) eucanthus birmanus Lindberg, 1943 [Myanmar]

(synonym: E. birmanus aequatorialis Dussart et Fernando, 1985; New Guinea)

11. Caudal rami relatively short with $\mathrm{L} / \mathrm{W}<4.1$; innermost caudal seta subequal to rami length and nearly 2 times as long as outermost seta ................................................ 12

- Caudal rami longer, innermost seta shorter .................. 13

12. Caudal rami very short, $\mathrm{L} / \mathrm{W}<3$; inner spine of $\mathrm{P} 5$ subequal to outer seta

E. (D.) ibleicus Pesce et Galassi 1987 [Caves in Italy]

-Caudal rami longer with $\mathrm{L} / \mathrm{W}=3.5-4$; inner spine of P5 2 times as long as outer seta

E. (D.) leptacanthus Kiefer, 1956 [Venezuela]

13.Caudal rami with small denticles along outer edge; inner spine of P5 1.5 times shorter than outer seta .................

E. (D.) microdenticulatus Lindberg, 1939 [India]

- Caudal rami with strong denticles along outer edge; inner spine of P5 longer than outer

14. Caudal rami long $\mathrm{L} / \mathrm{W} 5-5.5$

E. (D.) festivus Lindberg, 1955 [Mexico]

Caudal rami long L/W 4.3-5

E. (D.) pseudoensifer Dussart, 1984

(synonym: E. chihuahuensis Suarez-Morales et Walsh, 2009?)

\section{Eucyclops (Macrurocyclops) subgen.n.}

Type species: Eucyclops macrurus (G.O. Sars, 1863).

Caudal rami smooth with only few spinules near lateral setae inserting place, P5 with weak inner spine about as long as leg length or slightly longer; A1 12-segmented relatively short in the most species, just reaching to the first free thoracal somite, with narrow or even invisible hyaline membrane. The subgenus includes 8 species mainly with tropical distribution. Areal of the type species E. macrurus described from Scandinavia by Sars covers Holarctic [Dussart, Defaye, 2006].

\section{Eucyclops (Macrurocyclops) macrurus (G.O. Sars, 1863) \\ Fig. 9.}

FEMALE. Body length without caudal setae 1100-1300 $\mu \mathrm{m}$. Yellowish or sometime brown in color. Cephalotorax about as long as width. $4^{\text {th }}$ thoracal somite with long setae laterally. Genital double-somite 1,1 times as long as wide. Caudal rami very long, $8-10$ times as long as wide, parallel or slightly divergent, without lateral serra but with few small denticles near lateral seta insertation place. Caudal rami about as long as three last abdominal segments. Outermost seta short and weak, 1.2 times longer than dorsal seta. Lateral seta small and weak, about as long as ramus width. Innermost seta 2 and more times as long as outermost seta. Distal setae ratio beginning from outermost: 1:4.8:6:2. Antennules 12-segmented, relatively short, just reaching the first free thoracal somite or even shorter; three distal segments with very narrow sometimes invisible hyaline membrane. The $12^{\text {th }}$ segment sometimes has fine serration on surface of segment (see Fig. 9D) Basipodite of antenna on caudal side with few long hairs in position 1 (close to $E$. serrulatus); other ornamentation like in Fig. 6G; on frontal side with long diagonal raw of denticles and with a group (8-10) of relatively short denticles near exopodite insertation place (see Fig. 9H). Swimming legs 3-segmented. Exp spine formula 3/4/4/3. Distal endopodite P4 with L/W ratio about 2.5 (2.4-2.7). Distal inner spine 1.25 (1.1-1.3) times as long as outer spine and about as long as segment itself or even longer; distal seta just reaching middle of nearest spine. Coxal plate with three rows of short hairs; coxal spine homogeneously covered with long fine hairs; coxal segment ornamentation as in Fig. 9E. Rudimental P5 with relatively short and slender inner spine shorter than outer seta but clearly longer than segment itself; middle seta about 2 times as long as spine or longer.

MALE. Body length $800-900 \mu \mathrm{m}$. Caudal rami shorter than in female, 6.2-7.5 times as long as broad. Caudal setae length similar to female. Ornamentation of antenna basipodite similar to female but with less number of denticles in each group. P1-4 as in female but outer apical spine relatively shorter. P5 seta ratio like in female. Rudimental P6 armed with inner strong spine and 2 setae; middle seta shorter than spine; outer seta subequal to spine but significantly slender.

Key to subgenus EUCYCLOPS (MACRUROCYCLOPS) SPECIES

1. Caudal rami short with $\mathrm{L} / \mathrm{W}<5.5$..................................... 2

- Caudal rami more long with $\mathrm{L} / \mathrm{W}>6$............................ 4

2. Innermost seta of caudal rami shorter than outermost seta E. (M.) dubius (Sars, 1909) [Tanganika]

- Innermost seta of caudal rami at least 1.5 times as long as outermost seta

3. Inner spine of P5 short and weak, shorter than segment itself; innermost caudal seta more than 2 times longer than outermost seta

E. (M.) madagascariensis (Kiefer, 1926) (synonym E. congolensis Lindberg, 1951; Madagascar, Equatorial Africa)

- Inner spine of P5 longer than segment itself; innermost caudal seta shorter 

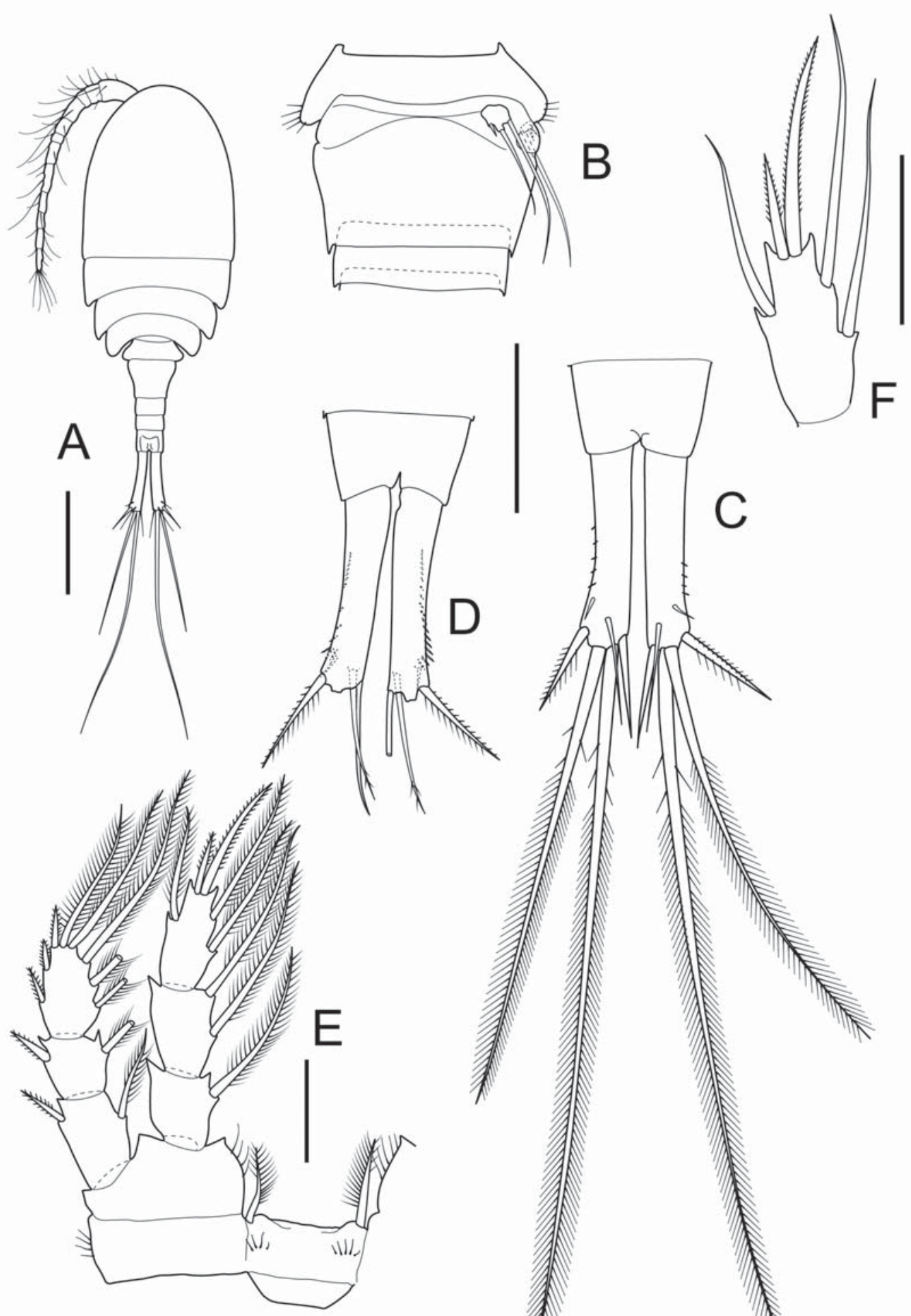

Fig. 10. Eucyclops (Sarsicyclops) semiserratus (Sars, 1909): A - habitus, dorsal; B - genital segment and P5, ventral; C - caudal rami, dorsal; D - caudal rami, ventral; E - P4; F - distal segment of endopodite P4. Scale bars: A - $200 \mu \mathrm{m}$; B, C, D - $100 \mu \mathrm{m}$; E $50 \mu \mathrm{m}, \mathrm{F}-50 \mu \mathrm{m}$. Habitus redrawn from Sars, 1909, others - orig..

Pис. 10. Eucyclops (Sarsicyclops) semiserratus (Sars, 1909): А - общий вид, дорсально; В - генитальный сегмент и Р5, вентрально; С — каудальные ветви, дорсально; D — каудальные ветви, вентрально; Е — P4; F — дистальный членик эндоподита P4. Масштабные шкалы: A $-200 \mu \mathrm{m} ; \mathrm{B}, \mathrm{C}, \mathrm{D}-100 \mu \mathrm{m} ; \mathrm{E}-50 \mu \mathrm{m}, \mathrm{F}-50 \mu \mathrm{m}$. Общий вид воспроизведен по Sars, 1909 , остальное - ориг. 
4. Distal exopodial spine in P4 very short, not longer than other spines in the segment .

...... E. (M.) maritimus (Alekseev et Monchenko, 1991)

[Caspian Sea]

- This spine clearly longer than other spines ......... E. (M.) persistens Monchenko, 1978 [Black Sea]

5. Innermost caudal seta about as 2 times as long as outermost seta...

........... E. (M.) macrurus (G.O. Sars, 1863) [Palearctic]

-This seta not more than 1.3 times as long as outermost seta

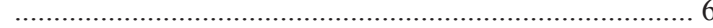

6. Caudal rami with small group of denticles near lateral seta insertation place

E. (M.) laevimargo (G.O. Sars, 1909) [Tanganika]

-Caudal rami absolutely naked even without small denticles near lateral seta insertation place ................................... 7

7. Caudal rami parallel

E. (M.) orthostylis Lindberg, 1952 [Volga River Delta]

- Caudal rami divergent. ........E. (M.) angustus (G.O. Sars, 1909) [Tanganyika]

\section{Eucyclops (Sarsicyclops) subgen.n.}

Type species: Eucyclops semiserratus (Sars, 1909).

Leg 5 with small inner spine, usually shorter than leg length and always not wider than medial seta; about half of length of outer seta or shorter. A1 12-segmented, distal segments with hyaline membrane smooth or denticulated. Caudal rami with well-developed serra.

Subgenus distributed in tropics and includes 6 species.

\section{Eucyclops (Sarsicyclops) semiserratus (Sars, 1909)} Fig. 10.

FEMALE. Small species, female length about $860 \mu \mathrm{m}$. Caudal rami 5-6 times as long as wide slightly bent on outer margin with partly reduced serra presented with relatively large denticles especially close to lateral seta insertation place. Lateral seta very small, less than ramus width. Distal seta ratio beginning from the outermost: 1:5:7.5:1.1. Dorsal seta subequal or even longer than outermost seta. Genital double-somite more broad than long. Th4 with short rare setae laterally. Antennula relatively long reaching the first free thoracal somite or longer, three distal segments with serrated hyaline membrane. Mouth appendages without clear seen differences from E.serrulatus. Swimming legs 3-segmented. Distal segment exopodite formula 3/4/4/3. Distal segment endopodite P4 with very long distal setae, inner spine about 2 times as long as outer spine and longer than segment itself; $\mathrm{L} / \mathrm{W}$ ratio of segment $<2$. Coxal spine in $\mathrm{P} 4$ with gap in hairs on outer margin similar to E.serrulatus.

MALE. Not described by Sars; description by Lindberg [1951] seems like doubtful due to large difference between small and large females identified as same species.

\section{Key to subgenus EUCYCLOPS (SARSICYCLOPS) SPECIES}

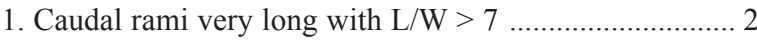

- Caudal rami not more than 6 times as long as wide ........ 3

2.Length of adult females more than $1 \mathrm{~mm}$, caudal rami with tiny spinules at lateral edgeE. (S.) porrectus Kiefer, 1932

[Endemic (?) of lake Ohrid, Balkan peninsula, Europe]

-Length of adult females less than $0.9 \mathrm{~mm}$, caudal rami with strong denticles at lateral edge

E. (S.) crassispinosus Kiefer, 1932

[Upper Volta, Africa]
3. Caudal rami short with $\mathrm{L} / \mathrm{W}<5$, innermost caudal seta at least twice of outermost seta length ................................ 4

- Caudal rami longer with $\mathrm{L} / \mathrm{W}>5$, innermost caudal seta not more than 1.2 times as long as wide ....................... 5

4. Caudal rami very short nearly 3.2 times as long as wide with reduced serra, adult female about $0.75 \mathrm{~mm}$; innermost caudal seta at least 2.5 times as long as outermost seta ................... E. (S.) neocaledoniensis Dussart, 1984

[New Caledonia]

- Caudal rami about 4-5 times as long as wide with well developed serra; adult female about $1.2 \mathrm{~mm}$ long; innermost caudal seta not more than 2 times as long as outermost seta ........ E. (S.) nichollsi Brehm, 1950 [Tasmania]

5. Outer seta of P5 longer than medial seta; P4 Enp inner distal spine more than twice longer than outer spine .... E. (S.) semiserratus (Sars, 1909) [Endemic of Tanganyika?]

- Outer seta of 5 leg about 1.5 times shorter than medial seta, inner distal spine of P4 Enp less than 1.5 times longer than outer spine ..... ........E. (S.) spatharum Harding, 1942 [Eastern Afrika]

\section{Eucyclops (Mrazekicyclops) subgen.n.}

Type species: Eucyclops stuhlmanni (Mrazek, 1895). Small cyclopids, female length usually less than $1 \mathrm{~mm}$. Subgenus unites females with 11-segmented antennule and two types of caudal rami construction. In E.stuhlmanni (Mrázek, 1895) and E. echinatus (Kiefer, 1926) caudal rami on dorsal surface with rows of setae and lateral serra. Two other species E. miurai Ito, 1952 and E. inarmatus Kiefer, 1932 have caudal rami naked both laterally and dorsally. These two groups possibly will become different subgenera especially if more species with 11-segmented antennule are found. Female antennule short; 3 distal segments without hyaline plate or with fine serrated narrow hyaline plate. The last segment of endopodite P4 with relatively long distal setae sometimes reaching distal tips of nearest spines but never extends beyond; inner spine of the segment usually longer than segment itself and significantly longer than outer spine. P5 with short and weak inner spine but long middle and outer setae. Subgenus includes 5 taxa, 2 species and 1 subspecies known from Afrika and 2 other species described from underground water in Europe and Japan.

\section{Eucyclops (Mrazekicyclops) stuhlmanni (Mrazek, 1895)}

Fig. 11.

FEMALE. Body length $850 \mu \mathrm{m}$. Abdomen significantly shorter than cephalothorax. Genital double-somite very wide, 0.7 times as long as broad. Forth free thoracal somite with long rare setae laterally. Caudal rami relatively short and wide, $\mathrm{L} / \mathrm{W}$ ratio 2.8 ; with 2-3 rows of spinules ventrally and short lateral serra occupies less than half lateral margin. Distal seta ratio beginning from the outermost: 1:6.5:10.3:0.9. Lateral seta as long as ramus width. Dorsal seta subequal to outermost seta. Antennula 11-segmented short, not reaching the distal end of cephalotorax; hyaline plate of 3 last segment absent or invisible; P4 coxal plate with 3 strong setae on each side; distal segment endopodite $\mathrm{L} / \mathrm{W}$ ratio varied (1.9-2.7); inner distal spine 1.3 times as long as outer spine; distal setae hardly reaching of nearest spines or shorter. Rudimental P5 with weak and short inner spine subequal or shorter than segment itself and two long setae 2-3 longer than segment. 


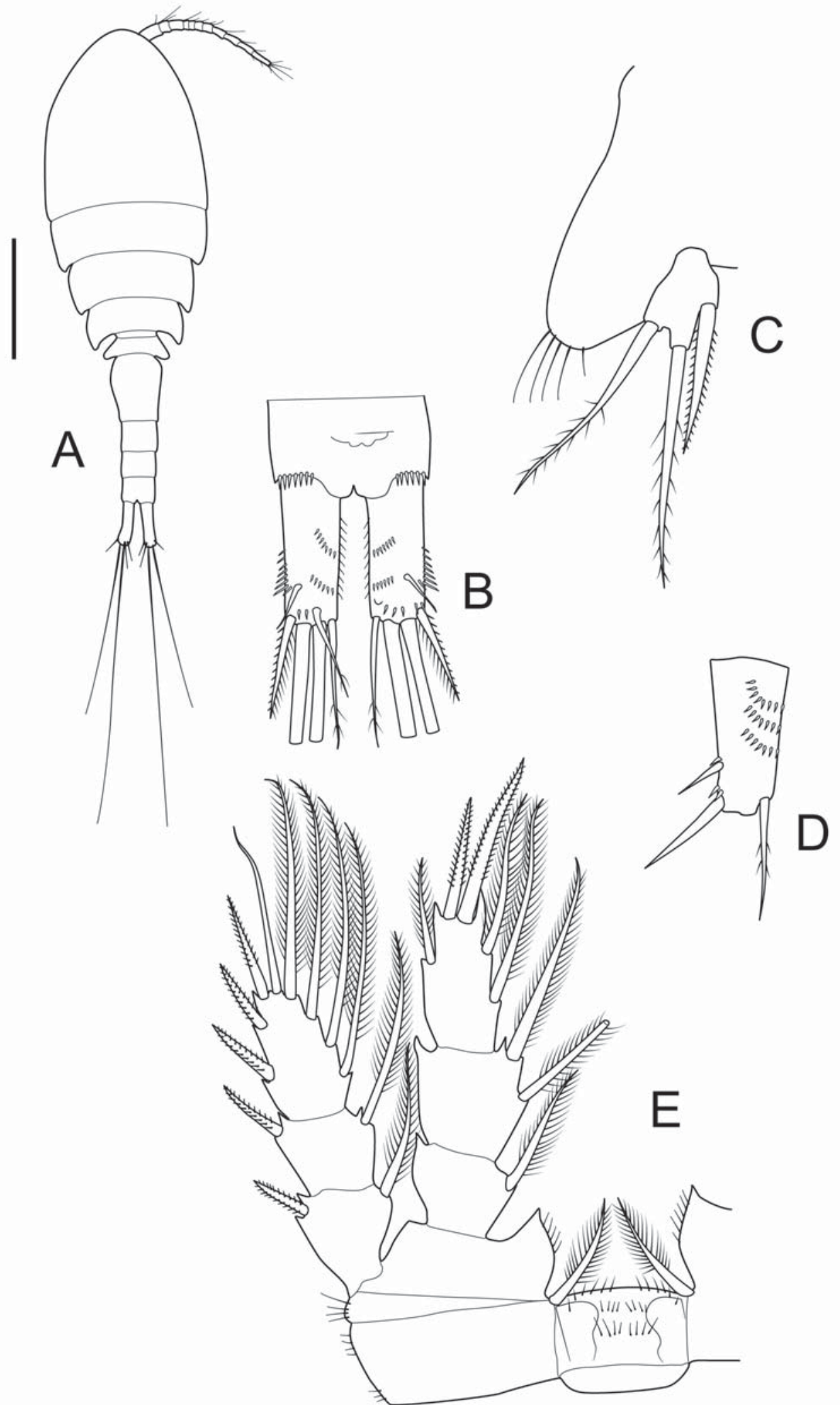

Fig. 11. Eucyclops (Mrazekicyclops) stuhlmanni (Mrazek, 1895): A — habitus, dorsal; B — caudal rami, dorsal; C — P5; D — caudal ramus, $O^{7}$; E - P4. Scale bar: A — $200 \mu \mathrm{m}$. Habitus redrawn from Mrazek, 1895, others - orig.

Рис. 11. Eucyclops (Mrazekicyclops) stuhlmanni (Mrazek, 1895): А - общий вид, дорсально; В — каудальные ветви, дорсально; С - P5; D - каудальная ветвь, О’; Е - Р4. Масштабная шкала: А - $200 \mu$ m. Общий вид воспроизведен по Mrazek, 1895, остальные - ориг. 

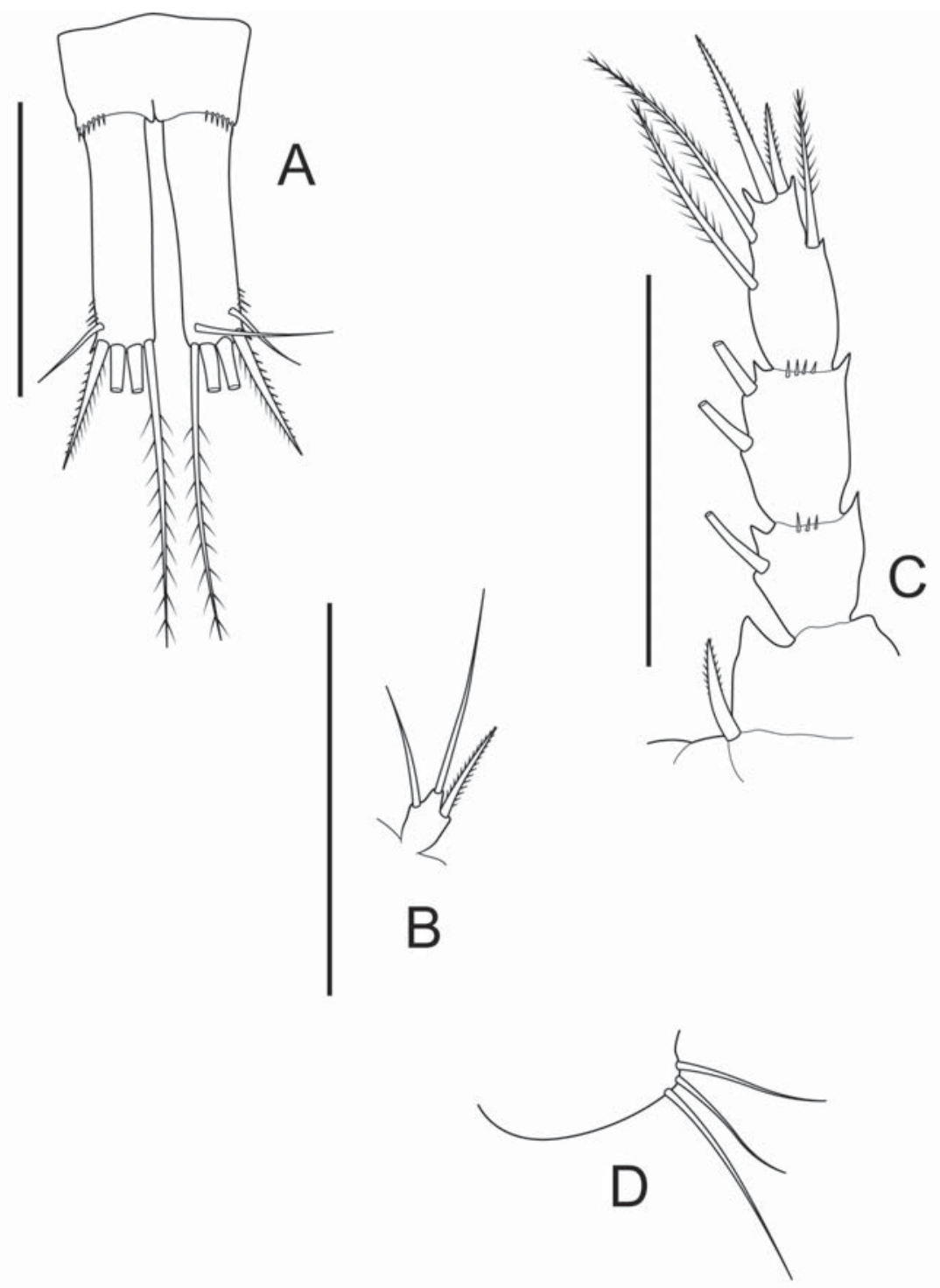

Fig. 12. Eucyclops (Subterrocyclops) subterraneus (Graeter, 1907): A — caudal rami, dorsal; B - P5; C - P4; D - P6, O'. Scale bars: $100 \mu \mathrm{m}$. Redrawn from Pesce \& Galassi, 1983 and Monchenko, 1974.

Pис. 12. Eucyclops (Subterrocyclops) subterraneus (Graeter, 1907): А — каудальные ветви, дорсально; В — P5; C - P4; D - P6, о7. Масштабные шкалы: $100 \mu$ m. Воспроизведено по Pesce \& Galassi, 1983 и Monchenko, 1974.

MALE. Body length $730 \mu \mathrm{m}$ or $85 \%$ of female length. Abdomen also significantly shorter than thoracal part. Caudal rami of the same proportions and armament as in female excepting three instead of two spinules rows on dorsal surface of caudal rami and almost reduced caudal lateral serra. Rudimental P6 with strong long inner spine and two significantly shorter outer setae.

COMMENTS. Kiefer [1952] described E.stuhlmanni tepidus from hot spring in Kenya as small female $(600 \mu \mathrm{m})$ with very short caudal rami (L/W ratio about 2 ) that possibly should be redescribed as a new species.

Key to SubGENUS EUCYCLOPS (MRAZEKICYCLOPS) SPECIES

1. Caudal rami with lateral serra and rows of spinules on dorsal surface

- Caudal rami naked
2. Inner weak spine of P5 shorter than segment length and many times shorter than outer seta ........ E. (M.) stuhlmanni (Mrazek, 1895) [East Africa] $(+$ E. s. tepidus $)$

- Inner weak spine of P5 long and strong, about as long as outer seta E. (M.) echinatus (Kiefer, 1926)

[Madagascar, Central Africa]

3. Innermost caudal seta plumose, forth distal segment of antennule very long due to junction of two segments ... E. (M.) miurai Ito, 1952 [caves in Japan]

-This seta naked, forth distal segment of antennule about the same length as adjacent ones .....E. (M.) inarmatus Kiefer, 1932 [Caves in Slovenia]

\section{Eucyclops (Subterrocyclops) subgen.n.}

Type species: Eucyclops subterraneus (Graeter, 1907). 
Antennule 12-segmented with short usually smooth hyaline membrane or sometimes without it. Caudal rami in most species divergent, on lateral edge with reduced serrula or sometimes without it. Most of species have both distal setae of third endopodal segment of leg 4 extending behind distal ends of nearest spines (only few species have long inner distal seta just reaching end of nearest spine). Comprises 14 species and 3 subspecies inhabiting ground water, living in caves, mosses, commensals of sponges.

\section{Eucyclops (Subterrocyclops) subterraneus (Graeter, 1907) \\ Fig. 12.}

FEMALE. Length $1700 \mu \mathrm{m}$ (with caudal setae, after Thiébaud), without caudal setae 600-950 $\mu \mathrm{m}$ [Monchenko, 1974]. Body elongated, transparent, nauplial eye without pigment. Forth free thoracal somite with dense long setae laterally but in some population naked. Genital double-somite road, 0.8 times as long as wide. Caudal rami shorter than $E$. macrurus, about 4-6 times as long as wide without serra laterally. Lateral seta usually shorter than ramus width. Innermost seta longer than ramus length and about 2.5 times as long as outermost seta. P5 with weak inner spine and 2 naked setae; medium seta about twice of spine length.

MALE. Body length 500-700 $\mu \mathrm{m}$, colorless. Caudal rami shorter than in females, 3-4 times as long as broad.

\section{Key to subgenus EUCyClOPS (SUbterRocyClops) SPECIES}

1. Caudal rami practically naked …………………............. 2

- Caudal rami with more or less presented lateral serra of denticles

2. Fifth pedigerous somite without hair-setae on lateral margins .

- This somite with hair-setae on lateral surface ............. 3

3. P1-4 spine formula $3 / 4 / 4 / 3$, inner distal spine of P4 Enp markedly longer than outer spine

E. (S.) graeteri (Chappuis, 1927)

[Underground water in Europe]

- P1-4 spine formula 3/4/3/3, inner distal spine of P4 Enp 1.5 times shorter than outer spine

E. (S.) linderi Lindberg, 1948

[Underground water in Australia]

4. P1-4 spine formula $2 / 3 / 3 / 3$

... (S.) propinquus Kiefer, 1932 [Eastern Africa]

- P1-4 spine formula $3 / 4 / 4 / 3$

5. Caudal rami L/W about 3 ; inner spine of P5 sub equal to outer seta .......... E. (S.) thienemanni Kiefer, 1930 [Java]

- Caudal rami more long, $\mathrm{L} / \mathrm{W}>3.5$; inner spine of P5 shorter than outer seta.....

... 6

6. Inner spine of P5 thin and seta-like; P4 coxal spine significantly longer than inner outgrowth of basal segment ......................... E. (S.) naphaeus Petkovski, 1971

[Caves in Macedonia]

- Inner spine of P5 strong knife-like, P4 coxal spine do not extending more than distal end os inner basal outgrowth

7. Caudal rami relatively long with $\mathrm{L} / \mathrm{W}>4, \mathrm{P} 4$ coxal spine never reaching distal end of inner basal outgrowth, in male inner spine in P6 strong and long...

E. (S.) glaber Kiefer 1935 [Cameroon]

- Caudal rami with L/W about 4, P 4 coxal spine practically reaching distal end of inner basal outgrowth; in male inner spine of P6 short and weak

E. (S.) chivahensis Lindberg, 1960

[Mountains in Afghanistan]

8. P1-4 spine formula $3 / 3 / 3 / 3$

E. (S.) fragilis (Kiefer, 1926) [Cameroon]

- P1-4 spine formula $3 / 4 / 4 / 3$......................................... 9

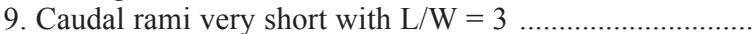

E. (S.) bryophilus Lindberg, 1950 [India]

- Caudal rami with L/W > 3 ........................................ 10

10. Caudal rami relatively long, L/W about $4-5$; innermost caudal seta as long as outermost seta

E. (S.) delachauxi (Kiefer, 1925)

[Underground water of Peru]

- Caudal rami shorter, with L/W about 4; innermost caudal seta markedly longer than outermost seta .................. 11

11. Innermost caudal seta more than 2 times as long as outermost seta ...... E. (S.) subterraneus (Graeter, 1907)

[Underground water of Europe]

- Innermost caudal seta less than 1.5 times as long as outermost seta

12. P5 inner spine 1.5-2 times shorter than outer seta; P4 coxal spine shorter or only reaching distal end of inner basal outgrowth....

........E. (S.) elburziensis Lindberg, 1941 [wells in Iran]

- P5 inner spine longer than or equal to outer seta ......... 13

13. P5 inner spine longer than outer seta; P4 coxal spine reaching far away of distal end of inner basal outgrowth E. (S.) nagasakai Ueno, 1934

[Underground water of Japan]

- P5 inner spine and outer seta sub-equal in length; P4 coxal spine only reaching distal end of inner basal outgrowth ................... E. (S.) torresphilipi Suarez-Morales, 2004 [pond in Chiapas, Mexico]

\section{Eucyclops (Speratocyclops) subgen.n.}

Type species: Eucyclops speratus (Lilljeborg, 1901).

Cyclopids of medial size. Females from 900 to $1400 \mu \mathrm{m}$. Antennule 12-segmented usually with smooth or fine serrated narrow hyaline membrane reaching to first free somite. Th4 somite with group of long setules laterally. Genital double-somite about as long as wide. Caudal rami of different length with L/W from 4 till 8 , always with serra on lateral side that variated in length and in size of denticles. A2 basipodite on caudal surface never has groups of hairs on the top. Coxal spine P4 homogenously covered with fine setules. P5 with strong spine usually longer than outer seta but shorter than medial seta, the spine is always significantly longer than segment itself. Male rudimental P6 with strong inner spine and 2 weak setae usually shorter than spine.

The subgenus includes 8 species inhabiting Palearctic and Tropics (E. (S.) troposperatus).

\section{Eucyclops (Speratocyclops) speratus (Lilljeborg, 1901)}

Fig. 13.

FEMALE. Body length 1000-1400 $\mu \mathrm{m}$. Cephalosome as long as wide. Last segment of prosome with group of long seta-like spinules in lateral margin. Genital double-somite as long as wide, seminal receptacle typical for Eucyclops. Caudal rami L/W ratio 5 (in $E$. (S.) biwensis), 6-8; with longitudinal row of small spinules along outer margin dorsally in distal half (but with significant variation in this row length in type group, range: $0.25-0.75$ of caudal rami length). 

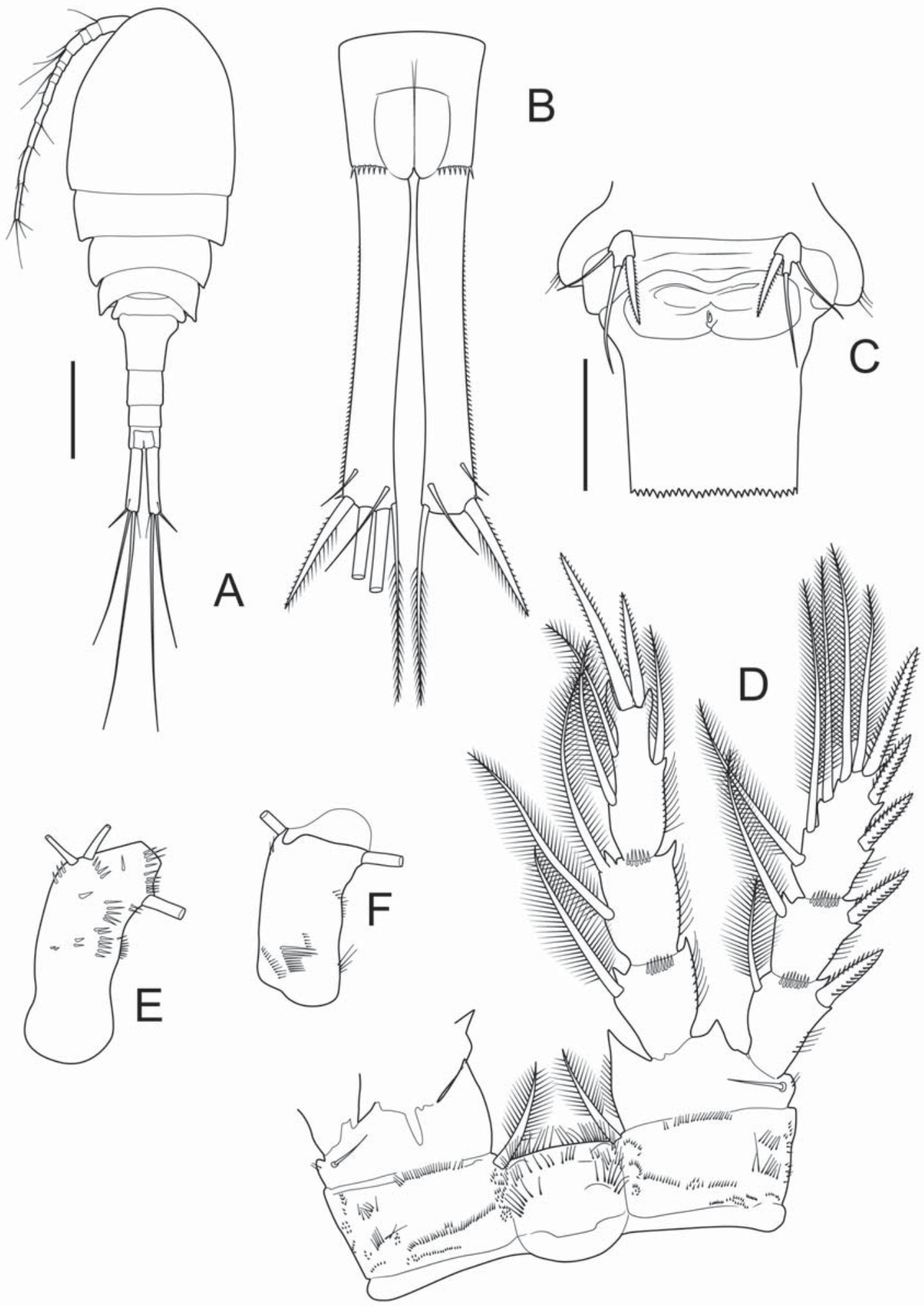

Fig. 13. Eucyclops (Speratocyclops) speratus (Lilljeborg, 1901): A — habitus, dorsal; B — caudal rami, dorsal; C — genital segment and P5, ventral; D - P4; E - A2 basipodite, anterior; F - basipodite of A2, posterior. Scale bars: A - $200 \mu \mathrm{m} ; \mathrm{C}-100 \mu \mathrm{m}$. Caudal rami redrawn from Lilljeborg, 1901, others - orig.

Рис. 13. Eucyclops (Speratocyclops) speratus (Lilljeborg, 1901): А — общий вид, дорсально; В — каудальные ветви, дорсально; C - генитальный сегмент и Р5, вентрально; D - P4; E — базиподит А2, вид спереди; F — базиподит А2, вид сзади. Масштабные шкалы: A $-200 \mu \mathrm{m} ; \mathrm{C}-100 \mu \mathrm{m}$. Изображение каудальных ветвей воспроизведено по Lilljeborg, 1901, остальные - ориг. 
Length proportion of four terminal setae, beginning from outermost: $1 / 5 / 8 / 1.5$. Dorsal seta about half as long as outermost seta, and of middle seta outer seta about half as long as inner seta. Antennule 12-segmented, reaching posterior border of first thoracic somite, with a finely serrated or smooth narrow hyaline membrane along last three segments. Antennal basipodite without group of hair-setae distally on caudal surface, with three parallel rows of spinules placed diagonally in central part and with two groups of spinules and setules laterally. On frontal face with several groups of spinules (as shown in Fig. 13E). Swimming legs Exp spine formula 3/4/4/3. P4 Enp3 elongated, 2.6 times as long as wide, with two strong distal spines, inner spine 1.4-1.6 times as long as outer spine. Inner edge of basis of P1-P4 with long setules. Coxal spine P4 homogenously covered with long setules. Coxa P4 with row of long spines (25-27) along distal border and several other groups of spinules and setules on caudal surface (as shown in Fig. 13D). Intercoxal plate P4 without protuberances, with long and dense setules distally, and with two other groups of long setules on caudal surface. P5 1-segmented, with knife-like long inner spine and two setae, outer seta subequal in length to spine, middle seta about 1.8 times as long as spine.

MALE. Body length 750-900 $\mu \mathrm{m}$. Caudal rami L/W ratio 4-6, innermost caudal seta shorter than ramus length. Rudimental P5 as in female. Rudimental P6 with strong inner spine and weak setae shorter than spine.

\section{Key to SUbGenus EuCYCLOPS (SPERATOCYCLOPS) SPECIES}

1. In caudal rami innermost seta shorter than outermost seta .......E. (S.) leschermoutouae Alekseev et Defaye, 2004 [well in Balearic Islands, Europe]

- Innermost caudal seta longer than or sub equal to outermost seta .................................................................... 2

2. Caudal rami long $\mathrm{L} / \mathrm{W}>5$ usually with more or less reduced serra ..................................................... 3

- Caudal rami less than 5 times as long as wide often with full serra .................................................................. 5

3.Inner spine of leg 5 very strong, knife-like; Caudal rami L/

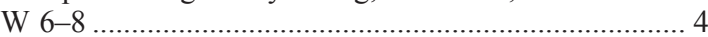

- Inner spine of leg 5 weak, seta-like; Caudal rami L/W about 5 ........................... E. (S.) biwensis Ishida, 1998

[Lake Biwa, Japan]

4. Coxal spine/seta homogenously covered with long thin hairs; P4 connecting coxal plate on distal edge with long dense hairs ...E. (S.) speratus (Lilljeborg, 1901) s.lat. [Palearctic?]

-Distal part of this spine/seta armed with short denticles and proximal part - with a long hairs; P4 coxal plate with few rare hairs ....E. $(S$.$) productus Kiefer, 1939$ [India]

5. Caudal rami 4-5 times as long as wide .......................... 6

- Caudal rami shorter ......................................................... 7

6. Caudal rami on lateral side with small short teeth of equal size ..... E. (S.) troposperatus Alekseev et Yusoff, 2013

[Malasia, South East Asea]

- Caudal rami on lateral side with teeth of different size, distal part of this serra presented with more or less long denticles at least twice longer than in proximal part .....

E. (S.) delongi Alekseev, 2019

[River Lena Delta, Far East of Asia, Arctic?]

7. Caudal rami very short, about 3 times as long as wide; inner edge of $\mathrm{P} 4$ basis hairless

E. (S.) dumonti Alekseev, 2000

[Eastern Siberia, Mongolia, China, Thailand]
- Caudal rami at least 3.5 times as long as wide; inner edge of P4 basis of with hair-seta

E. (S.) arcanus Alekseev, 1990

[Eastern Siberia, Mongolia, Northern China]

\section{Conclusion}

The large genus Eucyclops encounter about 100 species is subdivided here in three genera: Eucyclops Claus, 1893 with about 90 species and 7 subspecies, Isocylops Kiefer, 1957 stat.n. with 2 species and monotypic Stygocyclops Pleša, 1971 stat.n.

Previously described subgenus Tropocyclops (Defayeicyclops) was also erected to genus level and redescribed as genus Defayeicyclops stat.n.

Genus Eucyclops is subdivided in 9 subgenera: Eucyclops (Eucyclops) subgen.n. with 35 taxa, Eucyclops (Breviramocyclops) subgen.n. with 4 taxa, Eucyclops (Ciliocyclops) subgen.n. with 4 taxa, Eucyclops (Denticyclops) subgen.n. with 15 taxa, Eucyclops (Macrurocyclops) subgen.n. with 7 taxa, Eucyclops (Mrazekicyclops) subgen.n. with 5 taxa, Eucyclops (Sarsicyclops) subgen.n. with 6 taxa, Eucyclops (Speratocyclops) subgen.n. with 8 taxa, Eucyclops (Subterrocyclops) subgen.n. with 14 taxa.

Keys for 11 genera of subfamily Eucyclopinae, 9 subgenera and about 100 taxa of the genus Eucyclops are provided.

\section{Acknowledgements}

Authors really thankful to all colleagues listed in Material and methods chapter for their kind agreement to observe personal collections. I express a special gratitude to Dr. Hans Mittmann (Karlsruhe Natural History Museum, Germany) for his great help, productive efforts and invaluable assistance for everybody including myself dealing with Kiefer's reference collection. For this work, the Federal Collection No. 96-03-16, Zoological Institute of the Russian Academy of Sciences (St. Petersburg, Russia) was used. This work was conducted in accordance with the national research initiatives AAAA-A17-117041910019-2 and AAAAA19-119020690091-0 Russian Academy of Science (topics 65.4 and 65.5) and partly supported by Russian Foundation for Basic Research grant 17-04-00027.

\section{References}

Alekseev V.R., Haffner D.G., Vaillant J.J., Yusoff F.M. 2013. Cyclopoid and calanoid copepod biodiversity in Indonesia // Journal of Limnology. Vol.72. P.245-274.

Alekseev V., Defaye D. 2011. Taxonomic differentiation and world geographical distribution of the Eucyclops serrulatus Group (Copepoda, Cyclopidae, Eucyclopinae) // Defaye D., SuarezMorales E., von Vaupel Klein J.C. (eds.). Studies on Freshwater Copepoda: a Volume in Honour of Bernard Dussart (Vol. 16). Leiden: Brill. P.41-72.

Alekseev V., Dumont H.J., Pensaert J., Baribwegure D., Vanfleteren J.R. 2006. A redescription of Eucyclops serrulatus (Fischer, 1851) (Crustacea: Copepoda: Cyclopoida) and some related taxa, with a phylogeny of the E. serrulatus-group // Zoologica Scripta. Vol.35. No.2. P.123-147.

Claus C. 1893. Neue Beobachtungen über die Organisation und Entwicklung von Cyclops. Ein Beitrag zur Systematik der 
Cyclopiden // Arbeiten des Zoologischen Institut der Universität Wien. Bd.10. S.283-356.

Dussart B., Defaye D. 2006. World directory of Crustacea Copepoda of inland waters. Vol. II - Cyclopiformes. 2-e ed. Leiden: Backhuys Publ. 354 p.

Ishida T. 2002. Illustrated fauna of the freshwater cyclopoid copepods of Japan // Bull. Biogeogr. Soc. Jpn. Vol.57. P.37-106 .

Karanovic T. 2006. Subterranean copepods (Crustacea, Copepoda) from the Pilbara region in Western Australia // Records of the Western Australian Museum. Supplement Vol.70. 239 p.

Kiefer F. 1927. Versuch eines Systems der Cyclopiden // Zoologischer Anzeiger. Bd.73. H.11-12. S.302-308.

Kiefer F. 1930. Neue Cyclopiden von den Sunda-Inseln. (1. Mitteilung über die Cyclopiden der Deutschen Limnologischen Sunda-Expedition) // Zoologischer Anzeiger. Bd.89. H.11-12. S.319-322.

Kiefer F. 1937. Ein neuer Cyclopide (Crust. Copepoda) aus dem Ochridasee // Zoologischer Anzeiger. Bd.120. H.7-8. S.137143.

Kiefer F. 1952. Copepoda Calanoida und Cyclopoida // Exploration du Parc National Albert, Mission H. Damas (1935-1936), Institut des Parcs Nationaux du Congo Belge. T.21. P.1-136.

Kiefer F. 1957. Ruderfusskrebse (Crustacea Copepoda) aus dem Grundwasser des südlichen Oberrheingebietes. Prof. Robert Lais zum Gedachtnis! // Mitteilungen des Badischen Landesvereins für Naturkunde und Naturschutz, Freiburg im Breisgau. Neue Folge. Bd.7. H.1. S.53-68.

Kiefer F. 1960. Ruderfusskrebse (Copepoden). Stuttgart: KosmosVerlag Franckh. 99 S.
Lindberg K. 1951. Cyclopides (Crustacés Copépodes) // Résultats Scientifiques de l'Exploration Hydrobiologique du Lac Tanganika. T.3. No.2. 45-91.

Lindberg K. 1957. Cyclopides (Crustacés copépodes) de la Côte d'Ivoire // Bull. I.F.A.N. T.19A. P.134-179.

Löffler H. 1963. Zur Ostrakoden- und Copepodenfauna Ekuadors // Archiv für Hydrobiologie. Bd.59. S.196-234.

Mercado-Salas N.F., Suárez-Morales E. 2014. On Kiefer's American Eucyclops (Copepoda, Eucyclopinae): redescriptions and comments on the historical records of E. delachauxi, E. prionophorus, E. bondi and E. leptacanthus // ZooKeys. Vol.402. P.1-41.

Monchenko V.I. 1974. [Cyclops (Cyclopidae)] // Fauna Ukrainy. Vol.27. No.3. P.1-452 [in Ukrainian].

Morton D.W. 1990. Revision of the Australian cyclopidae, (Copepoda: Cyclopoida). II. Eucyclops Claus and Ectocyclops Brady // Marine and Freshwater Research. Vol.41. P.657-675.

Plesa C. 1971. Contribution à la connaissance des Cyclopides (Crustacea, Copepoda) des grottes et des eaux interstitielles de Suisse // Revue suisse de Zoologie. T.78. Fasc.4. P.833-850.

Pospisil P., Stoch F. 1997. Rediscovery and redescription of Austriocyclops vindobonae Kiefer, 1964 (Copepoda, Cyclopoida) with remarks on the subfamily Eucyclopinae Kiefer // Crustaceana (Leiden). Vol.70. No.8. P.901-910.

Sars G.O. 1927. The freshwater Entomostraca of the Cape Province (Union of South Africa). Part III: Copepoda // Annals of the South African Museum. Vol.25. P.85-149.

Thiébaud M. 1915. Copépodes // Catalogue des Invertébrés de la Suisse. T.8. P.1-125.

Responsible editor K.G. Mikhailov 